Adam Lityński (Sosnowiec)

\title{
Armenii droga do leninowsko-kemalowskiego rozbioru (1917-1921)
}

\section{ORMIAN MIEJSCE NA ZIEMI}

Wyżyna Armeńska liczy ok. 400 tys. $\mathrm{km}^{2}$ a powierzchnia dzisiejszej Republiki Armenii to tylko 29,7 tys. $\mathrm{km}^{2}$, czyli ok. $13,5 \%$ tego obszaru. To wynik historii regionu. Na południu Wyżyna Armeńska opiera się o Góry Kurdystańskie, na północo-zachodzie zaś sięga do Gór Pontyjskich oraz do Małego Kaukazu na północy i północo-wschodzie; Wyżyna Armeńska jest więc niemal ze wszystkich stron otoczona wysokimi górami. Największa część Wyżyny należy do Turcji, bardzo znaczna do Iranu, a nadto do Azerbejdżanu i Gruzji. Najwyższy masyw to Ararat (5122 m lub $5165 \mathrm{~m}$ ), należący do Turcji (w pobliżu granic z Iranem i Armenią); znajdują się tu (na wysokościach ponad $4000 \mathrm{~m}$ ) liczne stożki wulkaniczne, a teren jest silnie aktywny sejsmicznie. Na tych wysokościach liczne są lodowce. Wyżyna Armeńska położona jest na wysokościach na ogół między 1000 a $1800 \mathrm{~m}$, średnio jest to $1700 \mathrm{~m}$. Więcej niż 40\% Republiki Armenii leży na wysokości ponad $2000 \mathrm{~m}$. Klimat na Wyżynie podzwrotnikowy kontynentalny. To na Wyżynie Armeńskiej znajdują się źródła rzek Eufratu, Kury, Araksu; ta ostatnia - dopływ Kury - to największa rzeka Armenii, z ujściem do Morza Kaspijskiego w Azerbejdżanie. Wyznaczające północno-wschodnią granicę Wyżyny Armeńskiej pasmo Małego Kaukazu przebiega przez terytorium wszystkich trzech republik Zakaukazia. W masywie Małego Kaukazu znajduje się największe w całym Kaukazie jezioro Sewan; w całości leży ono w granicach Armenii. 
Ludność dzisiejszej Republiki (3,6 mln) to w 96\% Ormianie, ale w diasporze Ormian szacuje się znacznie więcej niż w Republice Armeńskiej' Jednolitość etniczna dzisiejszej Armenii bierze się głównie z drastycznego zaboru ziem ojczystych Ormian.

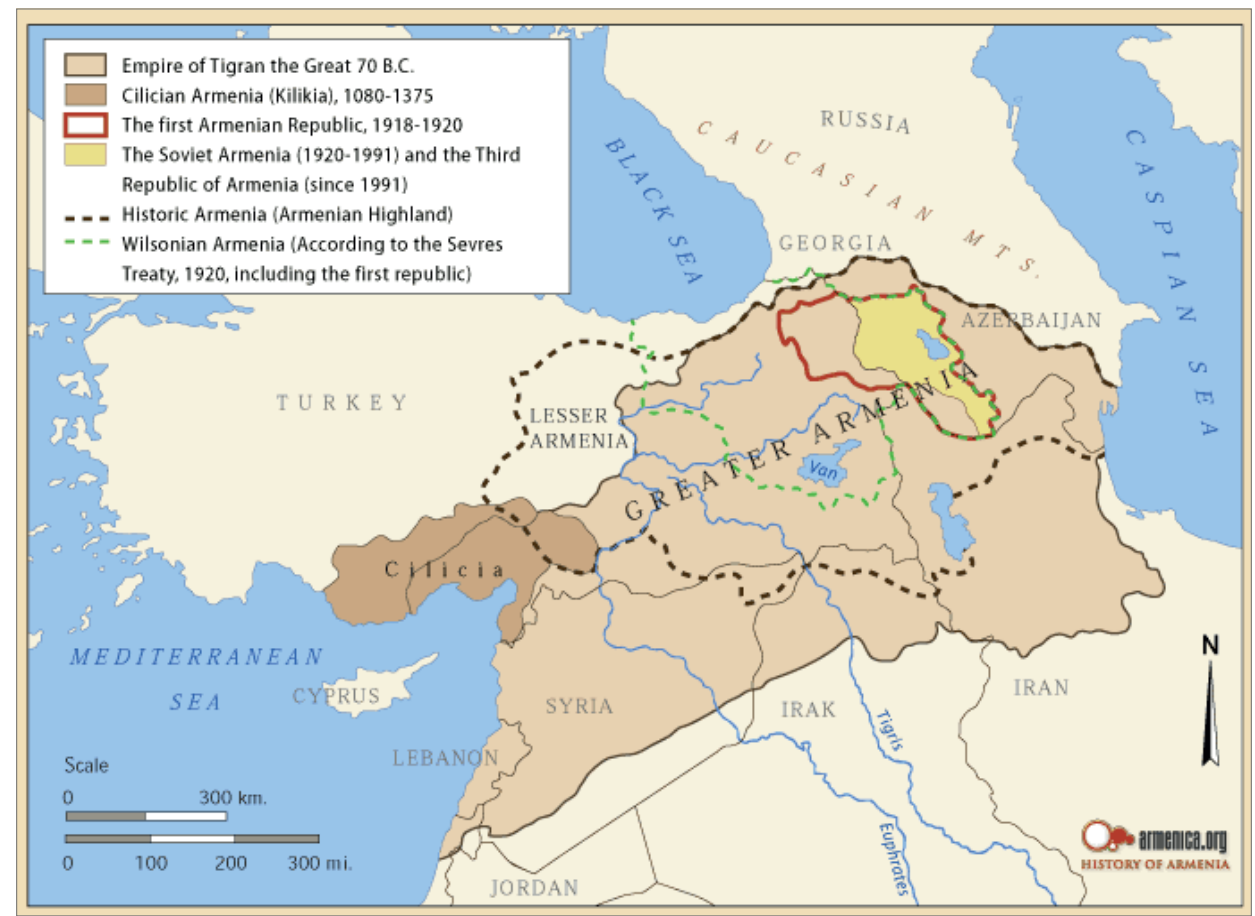

Źródło: https://alfanje.files.wordpress.com/2011/07/armenia-history-map.jpg [dostęp: 17.01.2018]

Plemię Armenów osiadłych na Wyżynie Armeńskiej pojawia się w I tysiącleciu p.n.e., ale badacze wskazują na bliskie pokrewieństwo języka armeńskiego i greckiego, sugerując że Armeńczycy osiedlili się w Azji Mniejszej w tym samym czasie, kiedy Grecy w Grecji (XX-XVII w. p.n.e?) $)^{2}$ Nie ma powodów, by w tym miejscu pisać o podbojach perskich, zwierzchnictwie rzymskim, o tworzeniu (XII do VI w. p.n.e.) zjednoczonego państwa armeńskiego, ale trzeba wspomnieć o chrystianizacji społeczeństwa armeńskiego już w IV wieku: na soborze w $317 \mathrm{r}$. chrześcijaństwo zostało ogłoszone jako religia panująca w państwie. Skutkowało to wykształceniem się świadomego narodu - Ormian, chrześcijaństwo których

${ }^{1}$ Ormianie mieszkają w ponad 60 krajach świata, m.in. w Ameryce i Europie 2 mln, na Bliskim Wschodzie 850 tys., w Rosji 420 tys., Gruzji 380 tys., Turcji 180 tys., Azerbejdżanie (Górski Karabach) 140 tys. Wielka Encyklopedia Powszechna PWN [dalej: WEP] XX 22.

2 Ibidem, II 307. 
odróżniało ich od sąsiadów. W ten sposób Ormianie stali się pierwszym na świecie narodem, a Armenia pierwszym państwem chrześcijańskim³ ${ }^{3}$ Armenia stała się przedmiotem podbojów Persji, Rzymu, Arabów, Bizancjum, Turków seldżuckich (XI w.), Mongołów, Turków osmańskich, rywalizacji turecko-perskiej (w 1555 r., a potem w 1639 r. Armenia została na długo podzielona między Turcję i Persję), wreszcie w XIX w. rywalizacji rosyjsko-persko-tureckiej. Podboje, krwawe walki i brutalne poczynania zaborców wyniszczających kraj, prowadzących do nędzy i głodu, skutkowały powtarzającymi się falami emigracji Ormian, m.in. do Indii. Emigranci tworzyli kolonie armeńskie w Azji i Europie, później także Ameryce, m.in. na północnych wybrzeżach Morza Czarnego (zwłaszcza Krym), na Bałkanach, na północnym Kaukazie, w licznych krajach Europy, w tym w Rzeczypospolitej (zwłaszcza Lwów i Kamieniec Podolski). Kolonie takie były ośrodkami rozwoju kultury i zachowania tożsamości narodowej, jak też pełniły funkcje polityczne. To z takich kolonii w pierwszej kolejności wyszły działania narodowowyzwoleńcze i tam rodziły się orientacje polityczne. Początki ożywionego ruchu (w historiografii armeńskiej przyjmuje się datę 1678 r.) wiązały się z latami panowania Jana III Sobieskiego i m.in. wiązały się z nadziejami pokładanymi w polityce prowadzonej przez króla Rzeczypospolitej Obojga Narodów. Dynamiczna ekspansja Rosji za panowania Piotra I kierowała się także ku brzegom Morza Czarnego oraz Kaspijskiego, a zbiegła się z rozczarowaniem narodowych działaczy armeńskich do polityki państw zachodniej Europy, co skutkowało ukształtowaniu trwałej orientacji prorosyjskiej. Dyplomacja rosyjska Piotra I nie zaniedbywała pertraktacji z reprezentantami ruchu narodowowyzwoleńczego narodów Zakaukazia, a zwłaszcza Ormian, którzy zobowiązali się w wypadku wojny Rosji z zaborcami do wystawienia 90-tysięcznej armii ${ }^{4}$. Wojna i wspomagające ją działania powstańcze Ormian wybuchły w 1722 r., ale po szybkich sukcesach i zdobyczach terytorialnych (m.in. Baku) Rosja szybko zawarła pokój z Persją (1723) i Turcją (1724). Nadzieje Ormian nie zostały spełnione, ale jednak orientacja prorosyjska umocniła się. Przyjęcie Królestwa Wschodniej Gruzji pod protektorat rosyjski (1783) i rozpoczęcie (trwającej ponad dwieście lat) wojskowej obecności rosyjskiej w Gruzji ${ }^{5}$ wzmacniało prorosyjskie myślenie działaczy ormiańskich. Na początku XIX w. wojny rosyjsko-perskie (1804, 1826-8), rosyjsko-tureckie, rosyjsko-francuskie (wielka ofensywa napoleońska) i związane z nimi manewry dyplomatyczne przyniosły w końcowym efekcie przyłączenie Kaukazu oraz Armenii Wschodniej do Rosji, co okaże się trwałe. Zdobycie przez gen. Iwana Pa-

${ }^{3}$ M. Zakrzewska-Dubasowa, Historia Armenii, Wrocław-Warszawa-Kraków 1990, s. 42, passim; WEP II 308; Geschichte Armeniens, http://honorarkonsulat-armenien.de/geschichte.htm [dostęp: 15.01.2018].

${ }^{4}$ M. Zakrzewska-Dubasowa, op.cit., s. 160.

${ }^{5}$ A. Furier, Gruzja niepodległa - od monarchii do republiki, Szczecin 2015, s. 47. 
skiewicza Erewania (01.10.1827 r.) zostało przez Ormian przyjęte jako symboliczne wyzwolenie ich ojczyzny ${ }^{6}$, ale gdy przedłożyli carowi projekt autonomii dla Armenii, spotkali się z odmową. Rozpoczęta niezwłocznie po zawarciu pokoju rosyjsko-perskiego wojna rosyjsko-turecka (1828-1829) zakończyła się znowu dużym sukcesem Rosji (na froncie bałkańskim zagrożony był nawet Stambuł), zaś zawarty pokój dawał Ormianom prawo repatriacji, co uczyniło łącznie około 140 tysięcy osób uzyskując na terytorium rosyjskim pomoc i ulgi podatkowe, bardzo ważne w sytuacji skrajnego wyniszczenia kraju i powszechnej nędzy.

W 1844 r. ustanowione zostało Namiestnictwo Kaukazu (całego Kaukazu), co było nowością, ale miało swoje wzory w Królestwie Polskim (Kongresowym), a w Finlandii ustrój utrzymywał się w daleko idącej samodzielności (Finlandia była Wielkim Księstwem). Utworzenie namiestnictwa było wyrazem uwzględniania odmienności terenu ekspansji terytorialnej Rosji. W Petersburgu utworzono Komitet Kaukaski dla spraw administracyjnych. Namiestnictwo Kaukaskie dzieliło się na cztery gubernie 7 . Namiestnik podlegał bezpośrednio carowi, zaś wszystkie agendy lokalne oraz władze wojskowe podlegały namiestnikowi. Pierwszym namiestnikiem Kaukazu został książę Michał Woroncow ${ }^{8}$. Urząd namiestnika został przez Aleksandra III zniesiony (1883) i zastąpiony gubernatorem generalnym, ale w dalszym biegu historii zostanie przywrócony.

Wojna krymska (1853-1856) przyniosła Rosji na froncie kaukaskim sukcesy i zdobycze terytorialne w Armenii Zachodniej (tureckiej), ale na mocy postanowień pokojowych wszystkie strony ewakuowały okupowane terytoria. Po antytureckich narodowowyzwoleńczych powstaniach na Bałkanach i wojnie rosyjsko-tureckiej 1877-1878 w ostatecznych (po rewizji traktatu w San Stefano) postanowieniach kongresu berlińskiego (1878) nie znalazła się sprawa autonomii dla Ormian w Turcji.

Natomiast od ostatniego dziesięciolecia XIX w., za panowania sułtana Abdulhamida II, zwanego „krwawym sułtanem”, władze tureckie przystąpiły do rozwiązywania sprawy ormiańskiej w drodze organizowania masowych pogromów Ormian, także przez specjalne oddziały. Odbieranie życia odbywało się ze szczególnym ok-

${ }^{6}$ M. Zakrzewska-Dubasowa, op.cit., s. 167.

${ }^{7}$ P. Olszewski, Uwarunkowania historyczne i dzieje nowożytne regionu na tle europejskim, [w:] Wprowadzenie do studiów wschodnioeuropejskich, t. 4: Armenia, Azerbejdżan, Gruzja, red. M. Korzeniowski, D. Tarasiuk, K. Latawiec, Lublin 2013, s. 30, 32.

${ }^{8}$ Michaił Siemionowicz Woroncow, 1782-1856, książę od 1845, żonaty z Polką Elżbietą Branicką, córką hetmana Franciszka Ksawerego Branickiego; rosyjski generał i feldmarszałek, uczestnik wszystkich najważniejszych wojen Rosji toczonych za jego życia, wyróżnił się w czasie wojny z Napoleonem 1812; powiązany z tajnymi związkami dekabrystów; generał-gubernator Noworosji i namiestnik Besarabii; polityk uważany za człowieka światłego i liberała; jeden z najbogatszych ludzi w ówczesnej Rosji. WEP XXIX 583; pl.wikipedia.org/wiki/Michaił_Woroncow_(1782-1856) [dostęp: 21.11.2017]; P. Olszewski, Uwarunkowania historyczne i dzieje..., s. 31. 
rucieństwem, gwałceniem kobiet. Na ogół były to bestialskie zbrodnie, specjalnie zorganizowane przez władze tureckie. Liczba ofiar tylko w latach 90. doszła do 300 tysięcy osób, zaś około 100 tysięcy uciekło, szukając ratunku w całej Europie i Ameryce9. Ludność ormiańska w Turcji, licząca w 1882 r. 2600000 osób, w ciągu jednego pokolenia - po trzydziestu latach - spadła o pół miliona w 1912 r. $^{10}$

Sprawa tragicznego losu Ormian w Turcji uzyskała jakąś skromną szansę, gdy w warunkach rosnącego napięcia niemiecko-brytyjskiego na przełomie wieków doszło do nad wyraz ważnego porozumienia rosyjsko-brytyjskiego w sprawie Persji, Afganistanu i Tybetu ${ }^{11}$ (31.08.1907), które na ten czas zakończyło rywalizację dwóch potęg o kolonialne strefy wpływów na tym ogromnym obszarze i przybliżyło ukształtowanie się Trójporozumienia.

Dziewiętnastowieczny rozwój kultury w Armenii wiązał się z działalnością Kościoła ormiańskiego i wokół niego się skupiał. Zwłaszcza szkolnictwo prowadzone było głownie przez Kościół. Natomiast swoje pierwsze partie polityczne Ormianie powołali do życia u schyłku XIX wieku, w tym najważniejszą - Dasznakcutjun ${ }^{12}$. Dasznacy mieli program społeczny zbliżony do rosyjskich eserowców i, podobnie jak tamci, stosowali metody terrorystyczne, ale w walce nie z caratem, lecz z rządem osmańskim. Liczyli też na poparcie Zachodu dla dążących do wyzwolenia Ormian. W 1907 roku w programie dasznaków znalazł się postulat, by całe Zakaukazie jako republika demokratyczna weszło w skład Federacyjnej Republiki Rosyjskiej; zauważmy, że chodziło o republikę. Pojawiła

${ }^{9}$ M. Zakrzewska-Dubasowa, op.cit., s. 213; B. Bruneteau, Wiek ludobójstwa, tłum. B. Spieralska, Warszawa 2005, s. 53-55; M.I. Midlarsky, Ludobójstwo w XX wieku, thum. B. Wojciechowski, Warszawa 2010, s. 55 i n.; V.N. Dadrian, The History of the Armenian Genocide. Ethnic Conflict from the Balkans to Anatolia to the Caucasus, Oxford 1995, s. 155, passim; WEP XX, s. 21.

${ }^{10}$ M. Zakrzewska-Dubasowa, op.cit., s. 222.

${ }^{11}$ Sprawa jest dużej rangi i wieloaspektowa, toteż nawet skrótowe jej omówienie w tym miejscu nie jest możliwe. Najlakoniczniej: Afganistan uznany został za brytyjską strefę wpływów, Tybet w zasadzie też brytyjską, ale za pośrednictwem Chin, zaś Persja podzielona została na trzy strefy wpływów: północną rosyjską, południową brytyjską, środkową neutralną. Конвенция между Россией и Англией по делам Персии, Афганистана и Тибета 8 (31) августа 1907 г. http://www. hrono.ru/dokum/190_dok/19070818ru_gb.php [dostęp: 07.01.2018]. Bliżej na ten temat: A. Bartnicki, Konflikty kolonialne 1869-1939, Warszawa 1971, s. 45-47, 60.

12 Dasznakcutjun [sojusz], dasznacy: ormiańska partia narodowa, założona w 1890 roku w Tyflisie (Tbilisi) pod nazwą Ormiańskiej Federacji Rewolucyjnej. Początkowo opowiadała się za autonomią ormiańską w Turcji. Po rewolucji październikowej w Rosji opowiedziała się za oderwaniem Armenii od Rosji i budowaniem dużego terytorialnie państwa narodowego. Trwale największa i najważniejsza partia ormiańska. Leksykon historii świata: Rosja, red. W. Sienkiewicz, Warszawa 2001, s. 65; Leksykon historii powszechnej 1900-1945, red. S. Sierpowski przy współpracy S. Żerki, Poznań 1996, s. 88; WEP VI, s. 539; W. Materski, XX wiek - niepodległość i sowietyzacja: Tradycja państwowa a budowa suwerennych państw $w$ regionie, [w:] Wprowadzenie do studiów wschodnioeuropejskich, t. 4: Armenia, Azerbejdżan, Gruzja, op.cit., s. 67; P. Olszewski, Uwarunkowania historyczne i dzieje..., s. 37. 
się też $\mathrm{w}$ ich programie koncepcja podzielenia Zakaukazia na kantony według kryterium etnicznego ${ }^{13}$. Bliżej sprecyzowany program związku Zakaukazia z Rosją jawił się wcale nowocześnie (m.in. pięcioprzymiotnikowe prawo wyborcze dla obu płci; szeroka autonomia lokalna). Po rewolucji lutowej 1917 r. dasznacy stali się główną siłą polityczną ludności ormiańskiej.

Od początku XX w. zauważyć można skromne przejawy aktywizowania się ruchu robotniczego, który na wiosnę 1905 r. przybrał rozmiary powszechnych wystąpień, głównie strajkowych, antycarskich, ale już w 1906 r. fala ta opadła, natomiast zaczęła się reakcja i represje.

Wybuch pierwszej wojny światowej poprzedzały nie tylko dwie wojny bałkańskie (1912-1913), lecz także rozmaite i w różnych kierunkach biegnące działania dyplomatyczne, niektóre - jak najbliższa przyszłość wojny światowej pokaże zupełnie chybione. Władze carskie oczywiście podjęły kwestię Ormian w Armenii Zachodniej (tureckiej), żądając najpierw stosownych reform wewnętrznych poprawiających położenie Ormian, a potem nawet idąc znacznie dalej, bo żądając autonomii dla Armenii Zachodniej pod międzynarodowym nadzorem, co byłoby protektoratem rosyjskim, a nadto Rosji dawałoby preteksty do ingerowania w wewnętrzne sprawy Turcji ${ }^{14}$. Kiedy się zna późniejszy układ sił w nadciągającej wojnie, nie dziwi, iż ostro zareagowały Niemcy oświadczeniem, że wprowadzenie wojsk rosyjskich na wschodnie tereny Turcji będzie dla Niemiec powodem do wypowiedzenia Rosji wojny. Wojska rosyjskie latem 1913 r. stały skoncentrowane nad granicami tureckimi. Pierwsza wojna światowa łatwo mogła się zacząć nie od strzałów w Sarajewie, lecz w Armenii Zachodniej. Przeciwko Rosji wystąpiły dyplomatycznie także Wielka Brytania oraz Francja, co miało utrzymać Turcję w roli państwa buforowego, a nadto dawało kapitałom tych państw ważne koncesje, zwłaszcza na tureckich terenach w Azji. Równolegle jednak żywa działalność ormiańskiej diaspory i okrutne rzezie tureckie wynosiły sprawę ormiańską na czołówki gazet i fora salonów politycznych.

\section{POCZĄTEK WOJNY ŚWIATOWEJ I GENOCIDIUM ATROX 1915}

Pierwsza wojna światowa to w zakaukaskiej optyce była dość długo wojna rosyjsko-turecka, a na tym froncie aż do 1917 roku włącznie Rosja odnosiła sukcesy, zupełnie inaczej niż w Europie. Dowódcą rosyjskiego Frontu Kaukaskiego

13 Tekst programu cytuje R. Pipes, Czerwone imperium. Powstanie Zwiazku Sowieckiego, tłum. W. Jeżewski, Warszawa 2015, s. 20; zob. też P. Olszewski, Uwarunkowania historyczne i dzieje..., s. 49.

${ }^{14}$ P. Olszewski, Uwarunkowania historyczne i dzieje..., s. 42; także M. Zakrzewska-Dubasowa, op.cit., s. 224. 
i jednocześnie namiestnikiem Kaukazu w sierpniu 1915 r. mianowany został Mikołaj Mikołajewicz ${ }^{15}$, który wówczas pod naciskiem carowej został zwolniony ze stanowiska naczelnego wodza armii rosyjskich po klęskach wojsk carskich w Europie. Sukcesy rosyjskie na froncie kaukaskim były w znacznym stopniu spowodowane skrajną nieudolnością dowodzenia wojskami tureckimi, gdzie wszelkie rekordy indolencji pobił Enver ${ }^{16}$ Pasza, doprowadzając do zguby stutysięczną armię turecką ${ }^{17}$.

${ }^{15}$ Mikołaj Mikołajewicz, 1856-1929, wielki książę, generał, stryj cara Mikołaja II, syn Mikołaja I, generalny inspektor kawalerii (1895-1905), dowódca wojsk gwardii i Petersburskiego Okręgu Wojskowego (1905-1914); skłócony ze sprzyjającym Niemcom ministrem wojny Włodzimierzem Suchomlinowem; 14/01.08.1914 r. wydał odezwę do Polaków obiecując zjednoczenie ziem polskich pod berłem cara; od 08.1915 r. do 03.1917 r. namiestnik Kaukazu. Po rewolucji lutowej odsunął się od spraw publicznych i zamieszkał na Krymie jako osoba prywatna; opuścił Rosję (1919) na krążowniku brytyjskim; udając się do Włoch, a potem do Francji, gdzie zmarł. Na emigracji uważany za jednego z najpoważniejszych pretendentów do tronu rosyjskiego. Leksykon historii powszechnej 1900-1945 ..., s. 276; Leksykon historii świata: Rosja, op.cit., s. 171; Leksykon historii świata, red. A. Bartnicki, Warszawa 1998, s. 278.

${ }^{16}$ Enver Pasza, ur. 1881 w Stambule, zm. 1922 w Bucharze; turecki generał i polityk, jeden z przywódców ruchu młodotureckiego; 1909-1911 attaché wojskowy w Berlinie, uczestnik wojny włosko-tureckiej 1911-1912 oraz wojny bałkańskiej 1913; od 1914 minister wojny; odgrywał główną rolę w tureckim triumwiracie faktycznie rządzącym Turcją przed i w czasie I wojny światowej; przy pomocy niemieckiej dokonał reorganizacji armii oraz doprowadził do udziału Turcji w wojnie po stronie państw centralnych; po zawieszeniu broni jako przeciwnik Kemala Atatürka zbiegł na Kaukaz; szukał sprzymierzeńców wśród bolszewików, ale później stanął na czele antysowieckiego ruchu basmaczy w Azji Środkowej; zginął w walce z bolszewikami. WEP VIII 276; Leksykon historii świata, red. A. Bartnicki, ..., s. 107; W. Morawski, S. Szawłowska, Wojny rosyjsko-tureckie od XVII do XX wieku, Warszawa 2006, s. 171 i n. Samo słowo „pasza” (tur.), „,basza” (arab.) to w imperium osmańskim i państwach powstałych po jego rozkładzie honorowy tytuł dostojników cywilnych (gubernatorów prowincji, wezyrów) i wojskowych, używany także w tytulaturze drobnych dynastii lokalnych, stawiany po imieniu lub nazwisku; zniesiony w Turcji w 1934. WEP XX 367; Leksykon historii świata, red. A. Bartnicki..., s. 332.

17 Armia turecka nie była przygotowana do nowoczesnej wojny. Była wyczerpana i w złej formie psychicznej po przegranych wojnach włoskiej (1911-1913) oraz bałkańskich (1912-1913); źle dowodzona przez słabo wyszkolony korpus oficerski (który trzeba było wspomagać doradcami niemieckimi), zaopatrzenie wojska było niedostateczne i sprzęt wojskowy, amunicję, środki medyczne trzeba było w całości sprowadzać z zagranicy, a konkretnie z Niemiec, zaś na drogach były wrogie Serbia i Rumunia; duże odległości, zły stan dróg - wszystko to utrudniało oraz zmniejszało mobilność wojska. Militarne znaczenie Turcji polegało przede wszystkim na trzymaniu cieśnin czarnomorskich i tym samym odcięciu Rosji od jej sojuszników zachodnich. Wojna dla Turcji zaczęła się okrętowym ostrzałem artyleryjskim (29.10.1914 r.) Odessy, Sewastopola i innych obiektów, ale tureccy przywódcy polityczni nadzieje wiązali z frontem kaukaskim oraz z pomocą rosyjskich muzułmanów, którym sułtan-kalif ogłosił (23.11.1914 r.) dżihad, czyli świętą wojnę przeciwko odwiecznemu wrogowi - Rosji. Kiedy Turkom udało się zatrzymać ofensywę rosyjską w Armenii Zachodniej, wówczas Enver Pasza osobiście przybył na front kaukaski, by dowodzić zamierzoną przez siebie wielką ofensywą przez Kaukaz, Morze Kaspijskie, do Azji, przez Afganistan, na Indie. Całkowity brak rozeznania i ignorancja były zdumiewające. Był to grudzień 1914 r., a żołnierze 
Front kaukaski początkowo rozciągał się od Morza Czarnego przez Ardahan, Kars i dalej w kierunku południowym, przy czym armia turecka skoncentrowana została w rejonie dużego miasta Erzurum. W ten sposób działania wojenne przebiegały na terytorium Armenii Zachodniej (tureckiej). Niebywała klęska wojsk tureckich (styczeń 1915 r. - zob. przypis 17) skutkowała podjęciem wiosną 1915 r. ofensywy rosyjskiej, która przyniosła stronie rosyjskiej duże sukcesy, m.in. zdobycie Erzurum, przy dużych stratach tureckich. Armia rosyjska była wspierana przez miejscową ludność ormiańską oraz samorzutnie organizowane siły ormiańskie, a także gruzińskie. Wówczas rząd turecki, a faktycznie rządzący Turcją triumwirat (Enver Pasza, Talaat Pasza, Dżemal Pasza) wydał (15.04.1915 r.) polecenie wszystkim władzom lokalnym i wojskowym dokonać całkowitego wysiedlenia i mordowania Ormian ${ }^{18}$. Eksterminacja została przez najwyższe władze oficjalnie, urzędowo nakazana; ewentualny sprzeciw miał pociągnąc za sobą utratę piastowanego urzędu lub rangi wojskowej. W Stambule i innych miastach masowo aresztowano przede wszystkim ormiańską inteligencję, którą później po większej części zgładzono. Wojsko i policja oraz specjalne konne jednostki kurdyjskie, na wyraźne rozkazy władz tureckich, wypędzały „niewiernych” Ormian na pustynię Del-el-Dzor (Pustynia Syryjska) zmuszając do wielosetkilometrowego marszu w kierunku punktów zbornych, bez pożywienia, bez wody, bez schronienia, zaś w czasie tych marszów śmierci cały czas dokonywano masowych bestialskich zbrodni, zabijając małe dzieci na oczach matek, paląc żywcem młodych chłopców, zakopując ludzi żywcem w ziemi, spychając ze skał, masowo gwałcąc kobiety i dziewczynki, zmuszając je do erotycznych perwersji, które kończyły się zazwyczaj odcinaniem piersi lub wypruwaniem kiszek; wielu traciło zmysły. „Kto nie został zamordowany, ginął z głodu i epidemii. Del-el-Dzor stal się okrutnym cmentarzyskiem ludności armeńskiej. Ofiarą tureckich bestialstw padli również znani i wybitni przedstawiciele armeńskiej nauki i kultury (...). Podczas rzezi zginęło półtora miliona Ormian." ${ }^{19}$ Z ludobójstwem łączyło się zagrabienie ogromnego majątku²0.

\footnotetext{
jednego z korpusów otrzymali rozkaz pozostawienia w mieście Erzurum płaszczy i tornistrów, by łatwiej brnąć w głębokim śniegu! Temperatury wahały się między minus 20 a minus 25 stopni. Brakowało namiotów, opału na ogniska, nawet żywności. Z blisko stutysięcznej armii prawie 80 tysięcy żołnierzy zmarło z zimna i głodu. Resztę zlikwidowały wojska rosyjskie w styczniu 1915 r., a zarządzony odwrót był już tylko paniczną ucieczką. W. Morawski, S. Szawłowska, op.cit., s. 174-178, passim; J. Pajewski, Pierwsza wojna światowa 1914-1918, Warszawa 1991, s. 246-247; zob. także J. Reychman, Historia Turcji. Wrocław-Warszawa-Kraków-Gdańsk 1973, s. 284.

${ }_{18}$ M. Zakrzewska-Dubasowa, op.cit., s. 228; zob. też V.N. Dadrian, op.cit., s. 219 i n.

${ }^{19}$ M. Zakrzewska-Dubasowa, op.cit., s. 228; zob. też W. Morawski, S. Szawłowska, op.cit., s. $180 \mathrm{i} \mathrm{n.}$

${ }^{20}$ V.N. Dadrianop.cit., s. 222 i n.; B. Bruneteau, op.cit., s. 64.
} 
Ormianie próbowali się bronić, w tych warunkach z desperacją i do końca ${ }^{21}$. Po zakończeniu pierwszej wojny światowej liczbaludności ormiańskiej w Zachodniej Armenii z ponad $2 \mathrm{mln}$ spadła do ok. 0,5 mln.

Istniała rzadowa intencja mordu (B. Bruneteau). Triumwirat turecki oceniał to pierwsze ludobójstwo XX w. jako robotę dobrze wykonaną. Genocidium atrox: ludobójstwo dzikie, straszne, okrutne.

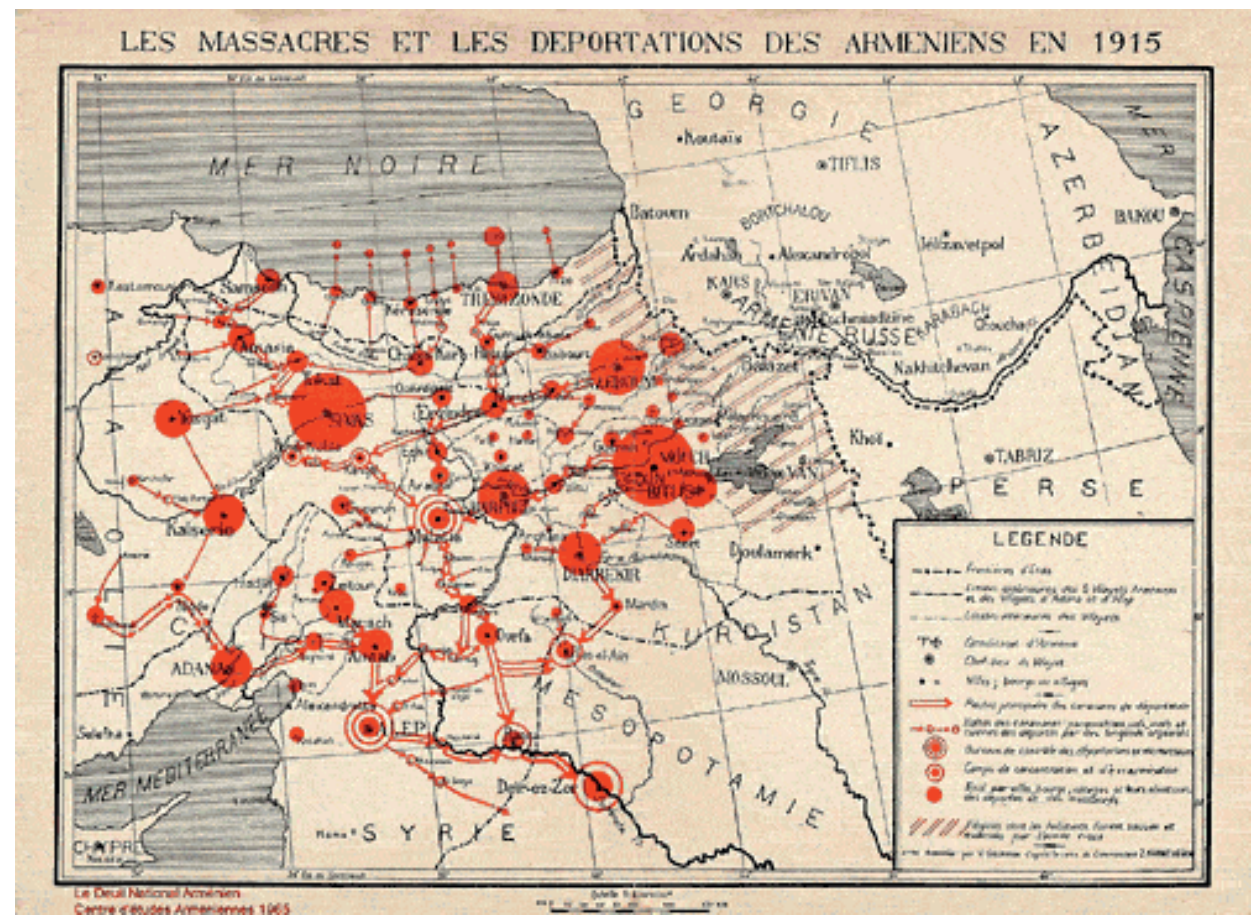

Źródło: http://www.genocide-museum.am/eng/mapping_armenian_genocide.php [dostęp: 03.11.2017]

W 90. rocznicę ludobójstwa Ormian Sejm Rzeczypospolitej Polskiej podjął (19.04.2005 r.) - przez aklamację - uchwałę składającą hołd ofiarom i wzywającą do utrwalenia tej zbrodni w pamięci.

${ }^{21}$ Do literatury pięknej trafiła obrona góry Mus. Mieszkańcy sześciu wsi, uzbrojeni tylko w 600 karabinów, bohatersko przez czterdzieści dni bronili się na górze Mus, a gdy mimo przeważających sił i artylerii wojsko tureckie nie potrafiło zdobyć góry, Turcy chcieli obrońców wziąć głodem. Obrońcy wysłali w morze trzech najlepszych pływaków z listami w trzech językach; jeden z nich dotarł na okręt wojenny francuski (blokujący południowe wybrzeża tureckie); okręty francuski i brytyjski zabrały 4058 ludzi, w tym 1563 dzieci. M. Zakrzewska-Dubasowa, op.cit., s. 229; WEP XX 21. 


\section{ROK 1917. O ROKU ÓW...}

Upadek caratu i działalność Rządu Tymczasowego skutkowały najpierw powstawaniem na Kaukazie rad robotniczych i żołnierskich, o większym znaczeniu w ośrodkach robotniczych Baku i Tyflisie. Niezwłocznie też miały miejsce reorganizacje natury administracyjnej. Mikołaj Mikołajewicz ustąpił ze stanowisk głównodowodzącego Frontu Kaukaskiego oraz namiestnika Kaukazu; do tej pierwszej funkcji powołany został przez Rząd Tymczasowy gen. Nikołaj Judenicz ${ }^{22}$. Ponadto w Piotrogrodzie ustanowiony został (30.05.1917 r.) tymczasowy urząd komisarza do spraw Kaukazu, a komisarzem uczyniono aktywnego członka Dumy Władimira Nabokowa ${ }^{23}$. Rząd Tymczasowy w poczuciu legalizmu uchylał się od wszelkich decyzji w kwestiach narodowych, przesuwając je do przyszłego Zgromadzenia Ustawodawczego.

Natomiast jako przedstawicielstwo Rządu Tymczasowego utworzony został Ozakom (Особый Закавказский Комитет - Osobyj Zakawkazskij Komitiet Specjalny Komitet Zakaukaski). Zasiadali w nim przedstawiciele kadetów ${ }^{24}$, ar-

${ }^{22}$ Nikołaj N. Judenicz, 1862 w Moskwie - 1933 w Cannes, uczestnik wojny rosyjsko-japońskiej, od 1907 r. generał, od 1915 r. dowódca Armii Kaukaskiej oraz (03.-04.1917 r.) Frontu Kaukaskiego; w 1918 r. wyjechał do Finlandii, a stamtąd przybył do Estonii. Od 1920 r. na emigracji. Leksykon. Historia świata. Rosja ..., s. 119; Leksykon historii powszechnej ..., s. 195; W. Morawski, S. Szawłowska, op.cit., s. 178 i n.; WEP XIII s. 52.

${ }^{23}$ Władimir Dmitrijewicz Nabokow, 1869-1922, prawnik, publicysta, polityk; pochodził z wielce arystokratycznej i zamożnej rodziny; ojciec był ministrem sprawiedliwości w rządzie carskim; W.D. Nabokow był ojcem znanego pisarza rosyjsko-amerykańskiego Władimira Nabokowa. Kierownik katedry kryminologii w Cesarskiej Szkole Prawa; w opozycji wobec caratu, za co spotykały go szykany i dwukrotne krótkie uwięzienie, wcześnie związany z partią Konstytucyjnych Demokratów, a później jeden z jej liderów, poseł do pierwszej Dumy; redagował manifest abdykacyjny Mikołaja Aleksandrowicza, brata cara Mikołaja II, na rzecz którego Mikołaj zrzekł się tronu; sekretarz Rządu Tymczasowego; w listopadzie 1917 wybrany do konstytuanty z okręgu Piotrogród z listy Konstytucyjnych Demokratów; jak wiadomo, sowieci wszystkich członków partii Konstytucyjnych Demokratów ogłosili wrogami ludu; od listopada 1918 był ministrem sprawiedliwości w separatystycznym „białym” rządzie Krymu; w kwietniu 1919 wyjechał wraz z rodziną z Rosji, najpierw do Londynu, a później do Berlina, gdzie zginął dość przypadkowo z ręki zamachowca, który miał zamiar dokonać zamachu na Pawła Milukowa, byłego ministra spraw zagranicznych Rządu Tymczasowego, jednej z najważniejszych niegdyś postaci w tym gabinecie. R. Pipes, Rewolucja rosyjska, tłum. T. Szafar, Warszawa 1994, s. 239, 253, 255 i inne; Владимир Дмитриевич Набоков - биография http:/to-name.ru/biography/vladimir-dmitrievich-nabokov.htm [dostęp: 17.10.2017].

${ }^{24}$ Kadeci (od KD - konstytucyjni demokraci): Partia Konstytucyjno-Demokratyczna, od 1906 r. Partia Wolności Ludu; utworzona w październiku 1905 r., skupiała głównie inteligencję i liberalną szlachtę, w programie miała wprowadzenie w Rosji monarchii konstytucyjnej, po 1917 r. jej członkowie opowiedzieli się za ustrojem republikańskim, początkowo stanowili główną siłę Rządu Tymczasowego, przeciwnicy bolszewików; bolszewicy ogłosili ich partią kontrrewolucyjną, partią wrogów ludu i nakazali aresztowania. O dekrecie Rady Komisarzy Ludowych w sprawie kadetów 
meńskich dasznaków (M.I. Papadżanow ${ }^{25}$ ), mienszewików, socjalistów-rewolucjonistów, musawatystów ${ }^{26}$. Przewodniczącym został pochodzący spoza Kaukazu Wasilij Charłamow. To postać o ciekawym życiorysie ${ }^{27}$ : pochodził z Kozaków dońskich, wykształcony, zawsze związany z regionem Donu i Kubania, o dużym stażu w Dumie. Wydaje się, że jego postać - spoza Kaukazu, ale Kaukazowi bliski - miała na celu pogodzenie ${ }^{28}$ przedstawicieli trzech narodów oraz kilku partii politycznych, wszystkich o często sprzecznych interesach i celach. W Ozakomie dominowali mienszewicy, w szczególności gruzińscy mienszewicy, a wśród nich postacią wybitną był Akaki Czchenkeli ${ }^{29}$. Siedzibą Ozakomu był Tyflis. Po wyjeździe Mikołaja Mikołajewicza - po abdykacji cara - ani komisarz Nabokow,

zob. W. Lenin, Dzieła wszystkie, Warszawa 1988, t. 35, s. 134. Leksykon historii świata: Rosja, op.cit., s. 139.

${ }^{25}$ Michaił Iwanowicz Papadżanow, 1869-1929, Ormianin, wcześnie związany z partią Konstytucyjnych Demokratów, członek Wschodniego Biura partii Dasznakcutjun - ormiańskiej partii narodowej, deputowany do IV Dumy, gdzie wchodził w skład frakcji Konstytucyjnych Demokratów; występował przeciwko bestialstwom tureckim wobec ludności ormiańskiej w Armenii Zachodniej; później podejmował wysiłki na rzecz załagodzenia konfliktu; członek Komisariatu Zakaukaskiego; zabiegał o mandat USA nad Armenią; jako przedstawiciel Armenii wyjechał na konferencję pokojową w Wersalu, a potem pozostał w Paryżu.

${ }^{26}$ Musawat [azer. - równość]: założona w 1911 r. w Baku pierwsza i najważniejsza ówcześnie azerska partia narodowa, liberalna, ale panislamska i panturkmeńska; jej współzałożycielem i niekwestionowanym liderem był Mehmed Emin Rasulzade, zwany ojcem niepodległości Azerbejdżanu; w początkowym okresie członkiem Musawatu był także Nariman Narimanow, przyszły przywódca komunistyczny ASRR.

${ }^{27}$ Wasilij Akimowicz Charłamow, ur. 1875 w chutorze Kriemienskoj-Ust w Bystrianskoj Stanicy w Okręgu (Obłasti) Wojska Dońskiego, zm. 1955 w Buenos Aires; ukończył filologię na Uniwersytecie w Moskwie, uczył w gimnazjum w Nowoczerkasku, autor prac na temat historii i etnografii Kraju Dońskiego; represjonowany; od 1906 członek partii Konstytucyjnych Demokratów (tzw. kadetów) później członek Komitetu Centralnego tej partii; deputowany do wszystkich czterech Dum z okręgu Wojska Dońskiego, w czasie I wojny światowej przedstawiciel Dońsko-Kubańskiej Sekcji Związku Ziem, wybrany szefem zjednoczonego rządu Południowo Wschodnich Wojsk Kozackich, Górali Kaukazu i Wolnych Narodów Stepów; wybrany członkiem Zgromadzenia Konstytucyjnego Rosji; po rewolucji bolszewickiej jako członek KC partii kadetów nawiązał kontakty z generałem Aleksym Kaledinem, atamanem Wojska Dońskiego, który jako jeden z pierwszych wystąpił przeciwko bolszewikom; w 1918 Ch. jako przedstawiciel Okręgu Dońskiego orientował się na Denikina; w 1920 wyemigrował, żył w Belgradzie, Pradze, po II wojnie światowej wyjechał do Argentyny. Василий Харламов, http://www.peoples.ru/state/politics/vasiliy_harlamov/ [dostęp: 16.10.2017]; http://www.hrono.info/biograf/bio_h/harlamov_va.php [dostęp:16.10.2017].

${ }^{28}$ Inaczej uważa A. Furier, op.cit., s. 120.

${ }^{29}$ Akaki Iwanowicz Czchenkeli, ur. 1874, zm. 1959 w Paryżu, Gruzin, studiował w Kijowie, Berlinie, Wiedniu, Londynie, prawnik, pisarz, w ruchu rewolucyjnym od 1898, od 1903 mienszewik, we władzach partii, członek IV Dumy, po rewolucji lutowej 1917 członek Komitetu Specjalnego do Spraw Zakaukazia (tzw. Ozakomu), premier w rządzie Zakaukaskiej Demokratycznej Federacyjnej Republiki, minister spraw zagranicznych Demokratycznej Republiki Gruzji, przedstawiciel dyplomatyczny Gruzji we Francji, po marcu 1921 r., we władzach na emigracji. W. Materski, Gruzja, Warszawa 2000, s. 333; A. Furier, op.cit., s. 120. 
ani nowy głównodowodzący Armią Kaukaską generał Judenicz nie mieli dość autorytetu i siły, by rzeczywiście rządzić trudną prowincją. Ozakom nie wykazywał inicjatywy do działań reformatorskich, ale uważał się za władzę najwyższą na Zakaukaziu. Powołał (27.04.1917 r.) komitety z komisarzami na czele w obwodach, guberniach i okręgach ${ }^{30}$; cieszyły się one jednak wśród ludności armeńskiej złą opinią. Przy Ozakomie tworzone były rady narodowościowe, w szczególności z poparciem dasznaków utworzono Armeńską Radę Narodową z siedzibą tam, gdzie Ozakom, tj. w Tbilisi.

Zarządzanie Zakaukaziem komplikowało się jeszcze na skutek istnienia i działalności rad robotniczych i żołnierskich w Tbilisi i Baku. W radach dominowali mienszewicy i eserowcy; ci pierwsi przeważali w Tbilisi i znajdowali wsparcie głowie wśród robotników przemysłowych. Natomiast Rada Baku z biegiem czasu przesuwała się bardziej w lewo, a nawet na pewien czas opanowali ją bolszewicy tworząc Komunę Bakijską (13.04.-25.06.1918 r.). Rada Baku miała większe wsparcie wśród żołnierzy, a tych zwłaszcza na początku roku 1918, po podpisaniu przez bolszewików separatystycznego traktatu brzeskiego (03.03.1918 r.) wielce zasilili dezerterzy. Ormiańscy dasznacy pozostawali w opozycji do komunistów, a nawet prowadzili z nimi walkę, a w bardziej umiarkowanym zakresie także z radami. Po rewolucji lutowej centralna władza rosyjska była dość iluzoryczna i słabła z upływem czasu, aż do obalenia przez bolszewików. Postępujący zanik władzy centralnej Rosji musiał skutkować podupadaniem Ozakomu jako przedstawiciela Rządu Tymczasowego, a w parze z tym musiało pójść zaznaczające się zróżnicowanie Kaukazu według obszarów etnicznych. Rok 1917, o którym tu mowa, to czas, gdy Kaukaz w granicach rosyjskich był terenem ucieczki nieszczęsnych Ormian spod bestialskiego ludobójstwa tureckiego. Była to masa ludzi wynędzniałych, bez swojego miejsca na ziemi, zrozpaczonych. Chociaż Azerowie nie mieli z okrutną masakrą Ormian bezpośredniego związku, to jednak byli muzułmanami i byli bliscy Turcji; niekiedy nazywano ich Turkami znad Morza Kaspijskiego ${ }^{31}$; to wystarczyło. To wówczas musiała się umocnić lojalność Ormian wobec rządu Rosji, łatwiej więc było o lojalność wobec rządu każdej Rosji, niezależnie od jej barw.

Politycy i ormiańscy działacze narodowi skupieni we wspomnianej Armeńskiej Radzie Narodowej dysponowali siłą zbrojną w postaci około 3 tysięcy uzbrojonych ochotników, zorganizowanych i zaopatrzonych jeszcze w czasach carskich, wspierających wcześniej Rosję w wojnie z Turcją. Zanim jeszcze Rząd Tymczasowy w Piotrogrodzie upadł, wyraził był zgodę na prośby Armeńskiej Rady Narodowej o ściągnięcie wszystkich żołnierzy armeńskich służących

\footnotetext{
${ }^{30}$ M. Zakrzewska-Dubasowa, op.cit., s. 230.

${ }^{31}$ A. Furier, op.cit., s. 125.
} 
w wojsku rosyjskim i stworzenie Korpusu Ormiańskiego pod zwierzchnością Rady $^{32}$. W ten sposób Rada dysponowała już pewną siłą zbrojną zanim bolszewicy objęli władzę w stolicy Rosji. Dasznakcutjun było jedyną partią ormiańską dobrze zorganizowaną, a od kiedy dysponowało jeszcze siłą zbrojną, stało się jedyną nadzieją Ormian pozostających w zrozumiałym szoku po tureckiej zagładzie i niepewnych przyszłości. Wojna Rosji z Turcją wszak trwała.

\section{PO BOLSZEWICKIM ZAMACHU STANU W PIOTROGRODZIE}

Bezpośrednio po bolszewickim zamachu stanu politycy mienszewiccy zwołali naradę przedstawicieli wszystkich sił politycznych Zakaukazia; bolszewicy opuścili zebranie na znak protestu przeciwko nieuznaniu ich Rady Komisarzy Ludowych w Piotrogrodzie. Na naradzie postanowiono powołać (28/15.11.1917 r.) w miejsce Ozakomu (reprezentującego nieistniejący już Rząd Tymczasowy) Komisariat Zakaukaski. Komisariat nosił strukturę rządu: w jego skład wchodziło dwunastu komisarzy (dwóch reprezentowało ormiańską partię Dasznakcutjun), każdy miał swój resort. Przewodniczącym został, a nadto przyjął teki komisarza (ministra) spraw zagranicznych oraz komisarza pracy gruziński mienszewik Eugeni Gegeczkori ${ }^{33}$. Komisariat nie uznał władz bolszewickich w Piotrogrodzie, z wzajemnością. Pierwotnie Komisariat miał na celu administrowanie Zakaukaziem, a w szczególności utrzymanie porządku w tych trudnych tygodniach, aż do powołania przez Zgromadzenie Ustawodawcze w Piotrogrodzie nowego rządu dla państwa rosyjskiego ${ }^{34}$. W deklaracji Komisariatu znalazło się sformułowanie, iż będzie działał do zebrania się Zgromadzenia Ustawodawczego, a w przypadku niemożności jego zebrania, do czasu powrotu na Zakaukazie jego członków ${ }^{35}$.

Po rozpędzeniu przez bolszewików Zgromadzenia Ustawodawczego (19/6.01.1918 r.) Komisariat Zakaukaski poprowadził politykę zdecydowanie antybolszewicką, w szczególności zawarł porozumienie z kozacką Radą Kubań-

${ }^{32}$ R. Pipes, Czerwone imperium..., s. 104.

${ }_{33}$ Eugeni Pietrowicz Gegeczkori, 1881-1954, ukończył prawo na Uniwersytecie Moskiewskim, adwokat, od 1903 z mienszewikami, aktywny działacz robotniczy w Kutaiskiej guberni, skąd wybrany został do Dumy, gdzie był jednym z liderów frakcji mienszewików; w 1917 r. członek prezydium Tyfliskiej Rady; minister spraw zagranicznych Gruzińskiej Republiki Demokratycznej; od 1921 r. - po upadku niepodległego państwa gruzińskiego i wcieleniu Gruzji do Rosji sowieckiej w gruzińskich władzach na emigracji.

${ }^{34}$ R. Pipes, Czerwone imperium..., s. 105.

35 »лишь до созыва Всероссийского учредительного собрания, а в случае невозможности его созыва (...) до съезда членов Учредительного собрания от Закавказья и Кавказского фронта«. Закавказский комиссариат, http://www.hrono.info/organ/ukaz_z/ru19170170.php [dostęp: 16.10.2017]. 
ską i z atamanem kozackiego Wojska Dońskiego Aleksiejem Kaledinem ${ }^{36}$. Kaledin był znienawidzony przez bolszewików i trudno się dziwić, skoro Kozacy, a w szczególności Kaledin, byli pierwszymi, którzy zareagowali negatywnie na bolszewicki zamach w Piotrogrodzie i podjęli walkę̨, a przez pewien czas stanowili jedyną liczącą się siłę mogącą zagrozić bolszewikom; później (w styczniu 1919 r.) Kozacy wesprą zbrojnie Denikina: Kozacy Kubańscy oraz Armia Dońska weszły - obok Armii Ochotniczej - w skład Sił Zbrojnych Południa Rosji $[\mathrm{SZPR}]^{38}$.

Jak wspomniano, rząd bolszewicki (Rada Komisarzy Ludowych - RKL) w Piotrogrodzie nie uznawał Komisariatu Zakaukaskiego. W grudniu 1917 r. RKL z jej przewodniczącym Leninem na czele rozpatrywała sytuację na Kaukazie i mianowała członka KC partii Stefanosa Szaumiana ${ }^{39}$ tymczasowym komisarzem rządu do spraw Kaukazu. Ten zaś zwrócił się do robotników Zakaukazia o tworzenie rad i przejmowanie władzy. Wówczas (na przełomie 1917/1918) utworzono w ramach piotrogrodzkiego Ludowego Komisariatu do Spraw Narodowości ${ }^{40}$ (którego komisarzem był Stalin) Wydział ${ }^{41}$ do Spraw Armeńskich, na czele którego

${ }^{36}$ Aleksiej M. Kaledin, 1861-1918, generał, podczas I wojny światowej dowódca korpusu i armii; w czerwcu 1917 r. wybrany atamanem kozackiego Wojska Dońskiego; po klęsce w walkach z bolszewikami popełnił samobójstwo. Leksykon historii świata: Rosja, op.cit., s. 121.

${ }^{37}$ Kaledin już w dniu zwycięskiego dla bolszewików przewrotu ogłosił przejęcie przez nich władzy za przestępcze i w imieniu wszystkich wojsk kozackich zadeklarował pełne poparcie dla Rządu Tymczasowego. Jednocześnie zaprosił członków Rządu Tymczasowego do przybycia do Nowoczerkaska - stolicy Kozaków dońskich. Rzeczywiście do Nowoczerkaska ściągali politycy i wojskowi wobec bolszewików opozycyjni (R. Wojna, W ogniu rosyjskiej wojny wewnętrznej 19181920. Warszawa 1975, s. 29-30). W odpowiedzi Rada Komisarzy Ludowych 11.12./28.11.1917 r. uchwaliła Dekret o aresztowaniu przywódców wojny domowej przeciw rewolucji (W. Lenin, Dzieła wszystkie. t. 35. Warszawa 1988, s. 121 i 448). A. Lityński, Rewolucji rosyjskiej rok pierwszy. Wybrane zagadnienia prawa karnego, [w:] Nil nisi veritas. Księga dedykowana Profesorowi Jackowi Matuszewskiemu, red. M. Głuszak, D. Wiśniewska-Jóźwiak, Łódź 2016, s. 482.

${ }^{38}$ R. Wojna, W ogniu rosyjskiej wojny wewnętrznej 1918-1920, Warszawa 1975, s. 142. Na temat struktur organizacyjnych SZPR zob. A. Lityński, Prawo Rosji i ZSRR 1917-1991 czyli historia wszechzwiązkowego komunistycznego prawa (bolszewików), wyd. 3, Warszawa 2017, s. 51-52.

39 Stepan Geworgi [Stefanos Gieorgijewicz] Szaumian, Ormianin ur. w Tbilisi w rodzinie kupieckiej; studiował na Politechnice w Petersburgu, Uniwersytecie Technicznym w Rydze, ukończył studia filozoficzne w Berlinie 1905; członek SDPRR od 1900; za co zesłany zbiegł do Niemiec, gdzie działał w środowisku rosyjskiej emigracji rewolucyjnej; poznał Plechanowa, Lenina; od 1903 z bolszewikami; od 1907 na czele bolszewików w Baku, pisał prace z zakresu teorii marksizmu; w 1917 przewodniczący Rady Rewolucyjnej Baku, rozstrzelany z 25 innymi komisarzami bakijskimi. Od jego imienia nazwano miasto w Górskim Karabachu - Stepanakert i w Armenii - Stepanawan.

${ }^{40}$ O strukturze i zadaniach tego komisariatu zob. A. Lityński, Prawo Rosji i ZSRR 1917-1991... , s. 68 .

${ }^{41}$ Używano również nazwy „komisariat” dla każdej wewnętrznej jednostki narodowościowej, co może być mylące, toteż tutaj używamy nazwy „wydział”. 
postawiono Warłaama Awaniesowa ${ }^{42}$; członkiem Wydziału był także poeta Vahan Teryan ${ }^{43}$.

Dasznakcutjun w listopadowych (1917 r.) wyborach do Zgromadzenia Ustawodawczego zdobyło 20\% wszystkich głosów na całym Zakaukaziu i niemal komplet głosów ormiańskich. Dla porównania warto dodać, że bolszewicy na tym samym terenie zdobyli 4,3\% głosów ${ }^{44}$. Pewne złudzenia co do ułożenia stosunków Zakaukazia z przyszłą demokratyczną, federalistyczną Rosją mogły w niektórych kręgach jeszcze istnieć, ale dla konstytucyjnych demokratów (tzw. kadetów), mienszewików i eserowców nie dłużej niż do rozpędzenia przez bolszewików Zgromadzenia Konstytucyjnego (19/6.01.1918). Tu można się doszukiwać wczesnej genezy pewnych rozbieżności postaw między siłami politycznymi Zakaukazia. Stale bowiem nad wszystkimi wydarzeniami i kierunkami polityki wisiała wojna.

Eskalacja rozkładu armii była zjawiskiem nieprzerwanym od końca $1916 \mathrm{r}$. Wydany już 15/2.03.1917 r. ,rozkaz nr 1” zezwalał żołnierzom wybierać swoich oficerów; odnosił się wprawdzie do garnizonu piotrogrodzkiego, ale faktycznie zaczął być stosowany także w innych jednostkach wojskowych ${ }^{45}$. Bolszewicki tzw. dekret z 26 października (8 listopada) 1917 r. o pokoju ${ }^{46}$ aktem prawnym wbrew nazwie bynajmniej nie był, lecz manifestem politycznym skierowanym do stron wojujących w wojnie światowej. Jego znaczenia politycznego dla wewnętrznej sytuacji w Rosji nie należy jednak nie doceniać: wszak wszystko, co się do tego momentu w 1917 roku w Rosji wydarzyło, jakoś tam swoje korzenie mia-

${ }^{42}$ Warłaam Aleksandrowicz Awaniesow [Awanesow] właśc.: Martirosow Suren Karpowicz, 1884-1930, Ormianin, lekarz, ukończył studia w Zurychu, najpierw w partii dasznaków, potem w socjaldemokracji armeńskiej, od 1903 r. w SDPRR najpierw u mienszewików, od 1914 r. u bolszewików; 10.-11.1917 r. członek Komitetu Wojskowo-Rewolucyjnego, funkcjonariusz Czeki, członek kolegium Czeki, 1920-1924 drugi zastępca kierownika wydziału specjalnego Nadzwyczajnej Komisji do Walki z Kontrrewolucją, Spekulacją i Przestępstwami, bliski współpracownik Dzierżyńskiego; członek Prezydium i sekretarz Wszechrosyjskiego Centralnego Komitetu Wykonawczego, zajmował jeszcze inne stanowiska. K. Kraj, Szlachcic-rewolucjonista Feliks Dzierżyński, Kraków 2015, s. 80; http://hrono.ru/biograf/bio_a/avanesovva.php [dostęp: 01.01.2017]; Энциклопедия государства и права, ред. П. Стучка, т. 2, Москва 1930, 856.

${ }^{43}$ Vahan Terian [Vahan Sukias Ter-Grigoryan], 1885-1920, Ormianin; studiował na Uniwersytetach Petersburskim oraz Moskiewskim, wybitny ormiański poeta romantyczny, liryczny, znany jako „Singer of Autumn”, niektóre jego wiersze śpiewane są do dzisiaj; po rewolucji bolszewickiej wszedł w skład wydziału ds. armeńskich w Ludowym Komisariacie do Spraw Narodowości, gdzie miał kontakty ze Stalinem i z Leninem; bardzo się troszczył i starał się pomagać uchodźcom ormiańskim; chorował na gruźlicę, nie chciał wyjechać na leczenie do Szwajcarii; nie stronił od alkoholu, zmarł na gruźlicę. Vahan Teryan. A Chronological Biography Compiled for Teryan.com Site, http:// www.teryan.com/vt_Biography_eng.html [dostęp: 01.01.2017].

${ }_{44}$ R. Pipes, Czerwone imperium..., s. 104, 107.

45 A. Lityński, Prawo Rosji i ZSRR 1917-1991..., s. 26.

46 История советской конституциии. Сборник документов. 1917-1957, Москва 1957, s. 9-11; История советской конституции (в документах) 1917-1956, Москва 1957, s. 44-47. 
ło w wydarzeniach na froncie, w kompletnej klęsce armii, w masakrze żołnierzy i w rezultacie w marzeniach o powrocie do domu; dodajmy: marzeniach realizowanych drogą masowych dezercji. Drugi z dekretów z 26 października (8 listopada) 1917 r. - dekret o ziemi ${ }^{47}$ (wszak szeregowi żołnierze to głównie chłopi) oraz zawarcie przez bolszewików rozejmu z państwami centralnymi (15/2.12.1917 r.) i przystąpienie do rokowań w sprawie pokoju separatystycznego - dopełniały miary przyczyn całkowitej dezorganizacji armii, co objęło również Zakaukazie. Armia Kaukaska, która wcześniej gromiła armie tureckie i zdobywała twierdze w Zachodniej Armenii, ulegała rozkładowi tak, jak armie rosyjskie w Europie. Dziesiątki tysięcy dezerterów wędrowało po kraju i wracało w rodzinne strony, by zdążyć przed oczekiwaną reformą rolną. Wiecowano, tworzono rady żołnierskie, dwukrotnie (w maju i grudniu 1917 r.) zbierały się samorzutne zjazdy żołnierskie Armii Kaukaskiej, padały żądania utworzenia władzy rad; dotyczy to także garnizonów na terenie Armenii; wśród aktywistów bolszewickich wyróżniał się Piotr Jakowlewicz Arwieładze ${ }^{48}$, a bolszewickim liderem żołnierzy Zakaukazia stał się Ormianin Grigorij (Grzegorz) Mikołajewicz Korganow ${ }^{49}$. Często dołączali do nich chłopi oczekujący reformy. Wędrówki uzbrojonych dezerterów naruszających porządek prawny rodziły wiele problemów, toteż rządzący Komisariat Zakaukaski wydał lokalnym radom polecenie rozbrajania żołnierzy wkraczających na Zakaukazie, ale to słuszne polecenie z kolei rodziło starcia; najbardziej krwawym było zdarzenie na stacji kolejowej (Szamkora, na wschód od Tyflisu), gdzie tłum muzułmanów zaatakował pociąg z żołnierzami, najpierw ich rozbroił, a następnie kilkuset bezbronnych Rosjan zamordowa ${ }^{50}$.

${ }^{47}$ История советской конституции. Сборник документов. 1917-1957..., s. 11-14; История советской конституции (в документах) 1917-1956..., s. 47-50.

48 Piotr (Pietr) Jakowlewicz Arwieładze, 1888-1919, pochodził z biednej rodziny wiejskiej z guberni kutaiskiej, w ruchu rewolucyjnym już od 1905; bolszewik, współredagował (1910) nielegalną gazetę „Tyfliski proletariat”; zmobilizowany w 1913, aktywny agitator rewolucyjny w wojsku; po rewolucji lutowej i rozpadzie armii działał zwłaszcza na Zakaukaziu; komisarz polityczny pułku leninowskiego 11. armii Armii Czerwonej, zginął w walkach pod Astrachaniem 19.03.1919 r. Г. Гарибджанян, Петр Арвеладзе, „Известия Академии Наук Армянской ССР, Общественные науки", 1957, № 11, s. 61-81.

${ }^{49}$ Grigorij Mikołajewicz Korganow, 1886-20.09.1918, Ormianin urodzony w Tyflisie, w ruchu rewolucyjnym od 1905 r., w 1907 r. usunięty za to z uniwersytetu, studia na Wydziale Historyczno-Filozoficznym Uniwersytetu Moskiewskiego ukończył w 1914 r.; zmobilizowany do Armii Kaukaskiej w randze oficera prowadził propagandę rewolucyjną; lider frakcji bolszewickiej na pierwszym oraz drugim zjeździe żołnierzy Armii Kaukaskiej; w 03.1918 r. członek Rewolucyjnej Rady Obrony Baku; w 04.1918 r. ludowy komisarz do spraw wojenno-morskich Bakijskiej Rady Komisarzy Ludowych; dowodził wojskami komunistycznymi Baku przeciw interwencji azersko-tureckiej, a po przegranej batalii zbiegł; rozstrzelany jako jeden z 26 ujętych komisarzy bakijskich. http:// ru.hayazg.info /Корганов_Григорий_Николаевич [dostęp: 01.01.2018].

${ }^{50}$ R. Pipes, Czerwone imperium..., s. 106. 
Ofensywa turecka wisiała w powietrzu, co musiało wywoływać najwyższy niepokój przede wszystkim Ormian, ale także Gruzinów; przeciwnie zaś u Azerów.

W Armenii dasznacy i mienszewicy mieli więc polityczną przewagę nad bolszewikami, z wyjątkiem żołnierzy, którzy opowiadali się za władzą bolszewicką. Bolszewicka piotrogrodzka Rada Komisarzy Ludowych Rosji pospieszyła więc z hasłami propagandowymi i 13 stycznia 1918 r. (31.12.1917 r.) wydała ,dekret" (w istocie była to proklamacja polityczna) O tureckiej Armenii ${ }^{51}$, zawierający oświadczenie Rady Komisarzy Ludowych [RKL] podtrzymujące ${ }^{52}$ stanowisko, iż naród ormiański ma prawo do samookreślenia aż do pełnej niezawisłości [независимости]. W odniesieniu do Armenii Zachodniej („tureckiej” Armenii), znajdującej się w tym momencie jeszcze (do początku 1918 r.) pod okupacją rosyjską, RKL zażądała wycofania wojsk tureckich, przeprowadzenia referendum, prawa do powrotu uchodźców, emigrantów oraz przesiedlonych w głąb Turcji; powołania milicji ludowej oraz ustanowienia rządu tymczasowego na wzór rady delegatów. Projekt tego dokumentu miał ponoć na zlecenie Lenina przygotować wspomniany poeta-bolszewik, funkcjonariusz Ludowego Komisariatu do Spraw Narodowości, Vahan Teryan ${ }^{53}$. Papier jest cierpliwy, ale wrażenie pewne wywołuje. Łatwo czytelne były zamierzenia Rosji względem jej odwiecznego wroga i przypominały lansowaną na forum międzynarodowym rosyjską koncepcję z lipca 1913 r. autonomii Armenii Zachodniej pod kontrolą międzynarodową, co w rzeczywistości miałoby być protektoratem rosyjskim.

\section{SEJM ZAKAUKASKI}

Rozpędzenie przez bolszewików Zgromadzenia Ustawodawczego (19/6.01. 1918 r.) miało na Zakaukaziu ten skutek, że Komisariat Zakaukaski pod koniec stycznia - zgodnie ze swoją deklaracją przy powołaniu - zwołał Sejm Zakau$\operatorname{kaski}^{54}$. Zgodnie z ustaleniami przedstawicieli wszystkich najważniejszych partii

51 История советской конституц̧ии (в документах) 1917-1956..., s. 97-98; История советской конституции. Сборник документов. 1917-1957..., s. 41.

52 Chodzi zapewne o nawiązanie do Deklaracji praw narodów Rosji z 15/2.11.1917 r., która m.in. głosiła równość narodów, ich suwerenność, prawo do samookreślenia aż o oderwania i utworzenia własnego państwa. История советской конституции (в документах) 1917-1956..., s. 45, 58; История советской конституции. Сборник документов. 1917-1957..., s. 10, 19-20; zob. też V. M. Chkhikvadze, The Soviet State and Law, tłum. Y. Sdobnikov, Honolulu 2000, s. 92.

53 Zob. Vahan Teryan. A Chronological Biography..., notatki pod datami: końcówka 1917 r. i początek 1918 r. Tamże informacja, że Teryan przez pewien czas był oficjalnym doradcą strony rosyjskiej podczas rokowań pokojowych w Brześciu.

${ }^{54}$ A. Furier, op.cit., s. 128; W. Materski: Gruzja, op.cit., s. 62-65. 
politycznych Zakaukazia w skład Sejmu Zakaukaskiego w 1/3 weszli wybrani z Zakaukazia deputowani do rozpędzonego przez bolszewików Zgromadzenia Ustawodawczego, a w 2/3 następni na listach biorących udział w wyborach do piotrogrodzkiego Zgromadzenia Ustawodawczego, w proporcji do uzyskanych przez listy głosów. W ten sposób w Sejmie Zakaukaskim znaleźli się ${ }^{55}$ : gruzińscy mienszewicy (32 mandaty), azerbejdżańscy musawatyści (29 mandatów) i ormiańscy dasznacy (27 mandatów); ponadto do Sejmu weszli reprezentanci socjalrewolucjonistów, muzułmańskiego bloku socjalistycznego, socjalfederalistów i nacjonalistów-demokratów ${ }^{56}$. Pierwsze posiedzenie Sejmu odbyło się 10 lutego w Tbilisi. Przewodniczącym obrany został Nikola Czcheidze ${ }^{57}$, socjaldemokrata, mienszewik, o dużym doświadczeniu politycznym.

Szczególną uwagę deputowanych zajmowała sprawa stosunków z Turcją i zamierzeń Turcji oraz Rosji względem Zakaukazia. Z uwagą odbierano i analizowano sygnały o przebiegu rozmów brzeskich w sprawie rosyjskiego pokoju separatystycznego, a całkowity rozkład armii rosyjskiej także na Kaukaziu budził wręcz grozę. Tymczasem całkowita klęska Rosji na froncie I wojny światowej oraz rewolucyjny chaos wykorzystała Turcja, która już w grudniu 1917 r. naruszyła rozejm ${ }^{58}$ i rozpoczęła ofensywę; w styczniu 1918 roku wojska tureckie zajęły prawie całą Armenię Zachodnią oraz wkroczyły na Zakaukazie. Bolszewicy pod wpływem uderzenia niemieckiego w Europie niemal na kolanach podpisali traktat brzeski (03.03.1918 r.), odrywający od Rosji ważną część Zakaukazia (Batumi, Kars) i wracający na Kaukazie do linii granicznej sprzed 1878 r., a tym samym oddali imperium osmańskiemu tereny zdobyte przez Rosję w rezultacie wojny 1877-1878 r., zamieszkałe przez Ormian i Gruzinów i uważane przez te narody za swoje miejsce na ziemi. Ponadto - na co rzadko zwraca się uwagę - traktat brzeski pozostawiał Turcji wolną rękę w kształtowaniu sytuacji politycznej w regionie ${ }^{59}$.

55 Źródła podają liczby nieco, ale nieznacznie, się różniące.

${ }^{56}$ A. Furier, op.cit., s. 128;

${ }^{57}$ Nikola Siemienowicz Czcheidze, ur. 1864 r. w rodzinie szlacheckiej w okręgu kutaiskim (Gruzja), zm. 1926 r. we Francji; od 1898 r. w SDPRR, od 1903 r. w jej sekcji mienszewickiej, uczestnik rewolucji 1905 r., deputowany do III i IV Dumy, Przewodniczący Piotrogrodzkiej Rady Delegatów Robotniczych i Żołnierskich od marca do października (września) 1917, Przewodniczący Wszechrosyjskiego Centralnego Komitetu Wykonawczego od lipca do 09.11(27.10.)1917 r.; później przewodniczący Zgromadzenia Ustawodawczego Gruzji; po agresji i okupacji Gruzji przez bolszewików rosyjskich wyemigrował wraz z rządem Gruzji do Francji; chory na gruźlicę popełnił samobójstwo. http://www.hrono.ru/biograf/bio_ch/chheidze_ns.php [dostęp: 20.10.2017]; A. Furier, op.cit., s. 128; R, Pipes, Rewolucja rosyjska..., s. 237, 256-257, 264, 311 i passim.

${ }^{58}$ Rozejm na froncie wschodnim pomiędzy Rosją a Niemcami, Austro-Węgrami, Bułgarią i Turcją - państwami prowadzącymi rokowania pokojowe w Brześciu Litewskim - podpisany został 15/02.12.1917 r., zaś 18/5.12.1917 r. w Erzindżan (Erzincan) podpisali taki dokument szefowie sztabów rosyjskiej armii kaukaskiej oraz armii tureckiej.

${ }^{59}$ Art. 4 traktatu z 3 marca 1917 r. pomiędzy Niemcami, Austro-Węgrami, Bułgarią i Turcją z jednej strony a Rosją z drugiej: „Rosja zrobi wszystko ze swej strony, by zapewnić natychmia- 
W tej sytuacji rząd - Komisariat Zakaukaski - zdecydował o podjęciu bezpośrednich rozmów z Turcją. Wcześniej przygotowywane rozmowy z Turcją rozpoczęto w Trapezuncie (Trabzonie) 12 marca 1918 r., a więc bezpośrednio po podpisaniu traktatu brzeskiego. Na czele delegacji Komisariatu Zakaukaskiego stał gruziński mienszewik Akaki Czchenkeli, a towarzyszyli mu pełnomocnicy ormiańscy i azerbejdżańscy. Na wieść o podpisaniu traktatu brzeskiego Sejm Zakaukaski momentalnie zakwestionował moc obowiązującą traktatu w odniesieniu do Kaukazu i postanowił dążyć do zawarcia odrębnego porozumienia z Turcją. Dopóki jednak kraje Zakaukazia nie ogłosiły niepodległości, dopóty formalnie stanowiły nadal część państwa rosyjskiego i nie sposób było uniknąć skutków podpisania przez rząd bolszewicki traktatu brzeskiego. Tymczasem wojska tureckie czyniły dalsze postępy - zajęły Ardahan i oblegały Kars - i w tej sytuacji rząd zakaukaski postanowił ustąpić i oficjalnie uznał traktat brzeski za podstawę do dalszych rokowań z Turcją ${ }^{60}$. Aby rozmowy miały walor rozmów międzynarodowych, niezbędne było ogłoszenie niepodległości, na co szczególnie nalegała strona turecka słusznie licząc, że będzie rokowała z partnerem słabszym nawet od przegranej Rosji. Wobec daleko idących tureckich żądań terytorialnych rozmowy zostały zerwane, zaś armie tureckie szły naprzód: mimo oporu Gruzinów padło (01.04.1918 r.) Batumi, mimo oporu Ormian padł (15.04.1918 r.) Ardahan. Właściwie poważniejszy opór stawiały tylko narodowe jednostki ormiańskie, tzw. Ormiańska Armia Narodowa ${ }^{61}$. Na terenie południowo-wschodnim wojska tureckie weszły (w czerwcu 1918 r.) do Persji zajmując rejon Tebrizu, strefę wpływów rosyjskich.

\section{ZAKAUKASKA DEMOKRATYCZNA FEDERACYJNA REPUBLIKA [ZDFR]}

Mając na względzie dramatyczną sytuację na froncie oraz nieustępliwe stanowisko Turcji w kwestii formalnego ogłoszenia oderwania się Zakaukazia od Rosji, Sejm Zakaukaski ogłosił (22.04.1918 r.) Zakaukazie niezależną od Rosji

\footnotetext{
stową ewakuację prowincyj wschodniej Anatolii i jej pełnoprawnego powrotu do Turcji. Dystrykty Erdehan, Kars i Batumi zostaną w podobny sposób i bezzwłocznie opuszczone przez rosyjskie wojska. Rosja nie będzie się wtrącać w reorganizację narodowych i międzynarodowych stosunków tych dystryktów, ale pozostawi ludności tych dystryktów sprawę przeprowadzenia tej reorganizacji w zgodzie z sąsiadującymi Państwami, w szczególności z Turcją." http://tnke.home.pl/armianiemiecka/Dokument/1918b.htm [dostęp: 28.10.2017]. Zob. też bliżej na ten temat: W. Materski, Georgia rediviva. Republika Gruzińska w stosunkach międzynarodowych 1918-1921, Warszawa 1994, s. 40-41; P. Olszewski, Polityka Ententy wobec Zakaukazia 1918-1921 (Zarys problematyki), „Acta Universitatis Lodziensis, Folia Historica" 1997, t. 59, s. 25.

${ }^{60}$ R. Pipes, Czerwone imperium..., s. 109.

${ }^{61}$ A. Chwalba, Samobójstwo Europy. Wielka wojna 1914-1918, Kraków 2014, s. 301; J. Pajewski, op.cit., s. 727; J. Reychman, op.cit., s. 286; M. Zakrzewska-Dubasowa, op.cit., s. 232.
} 
demokratyczną republiką: powstanie Zakaukaskiej Demokratycznej Federacyjnej Republiki ${ }^{62}$. Turcja uznała (28.04.1918 r.) republikę ${ }^{63}$. Wznowiono rokowania pokojowe z Turcją ${ }^{64}$. Wśród polityków zakaukaskich ścierały się orientacje separatystyczne z antyseparatystycznymi; te ostatnie były silne zwłaszcza wśród Ormian i Gruzinów, natomiast Azerowie zachowywali powściągliwość, ale w istocie liczyli na pomoc Turcji w rozwiązywaniu konfliktów z sąsiadami.

Poprzedni rząd (Komisariat Zakaukaski) po proklamacji ZDFR ustąpił. Powołano rząd tymczasowy z premierem Akakim Czchenkelim. Czchenkeli objął też tekę ministra spraw zagranicznych; gabinet liczył ponadto jeszcze dalszych dwanaście resortów (spraw wewnętrznych, wojskowych, finansów, sprawiedliwości, komunikacji, edukacji, rolnictwa, przemysłu i handlu, aprowizacji, opieki społecznej, pracy, urząd kontrolera państwowego). Wśród wewnętrznych ogromnych napięć, a nawet starć, zwłaszcza między muzułmańskimi Azerami a katolickimi Ormianami, w warunkach stałego postępu armii tureckiej, Ormianie i Gruzini znaleźli się w dramatycznym położeniu; ci pierwsi oczywiście zagrożeni byli wręcz biologicznym unicestwieniem - ze względu na dopiero co dokonywane akty tureckiego ludobójstwa na Ormianach i bardziej newralgiczne położenie geograficzne między Turcją a tureckim Azerbejdżanem. Teraz Turcja zaczęła naciskać na rozwiązanie ZDFR, stawiając ultimatum w tej kwestii. Wobec tego każdy z trzech narodów ZDFR próbował budować własne struktury administracyjne oraz szukać własnych rozwiązań spraw globalnych, swojego dalszego istnienia. Jest prawdopodobne, że przedstawiciele Azerbejdżanu w trakcie wznowionych (12.05.1918 r.) rokowań z Turcją prowadzili potajemne rozmowy z delegacją turecką w sprawie odrębnego traktatu między tymi dwoma krajami. Delegaci gruzińscy na pewno pertraktowali potajemnie z Niemcami, a być może to samo czynili Ormianie ${ }^{65}$. Tak nie mogło wyglądać wspólne państwo; to była w istocie efemeryda. Przetrwała zaledwie 35 dni. Azerbejdżanie zaproponowali tylko Gru-

${ }^{62}$ Jeden z deputowanych mówił: „ludy Zakaukazia stoją w obliczu tragicznego wyboru: albo ogłosić się nierozdzielną częścią Rosji i tym samym narazić na wszystkie okropności rosyjskiej wojny domowej, a potem stać się areną obcej inwazji, w tym wypadku tureckiej, albo proklamować niepodległość i własnymi siłami bronić fizycznego istnienia całego kraju. Kiedy rzecz sprowadza się do takiej alternatywy, jedynym wyjściem jest natychmiastowe proklamowanie politycznej niezawisłości i utworzenie niepodległej Zakaukaskiej Republiki Federacyjnej." Cyt. za R. Pipes, Czerwone imperium ..., s. 110.

${ }^{63}$ P. Olszewski, Uwarunkowania historyczne i dzieje..., s. 56.

${ }^{64}$ ZDFR niezwłocznie wysłała do zajętego przez Turcję Batumi delegację dla wznowienia rozmów z Turcją. Strona turecka wówczas zażądała wówczas oddania im linii kolejowej prowadzącej z Aleksandropola (obecnie Giumri) do Dżulfy leżącej w Nachiczewaniu, na pograniczu z Persją. Dawałoby to Turcji praktycznie panowanie nad całą Armenią. Wobec odmowy wojska tureckie wkroczyły do Aleksandropola. R. Pipes, Czerwone imperium..., s. 196.

${ }_{65}$ P. Olszewski, Uwarunkowania historyczne i dzieje..., s. 57. 
zinom utworzenie wspólnego państwa ${ }^{66}$, z pozostawieniem Armenii na zagładę. Gruzini odmówili, ale to dlatego, że im się trafiła - mogło się wówczas zdawać lepsza perspektywa, a mianowicie szansa na uzyskanie wsparcia ze strony Niemiec, z którymi Gruzini od pewnego czasu prowadzili poufne rozmowy. Niemcy chciały zatrzymać Kaukaz w swoich rękach, zaś turecką ekspansję ukierunkować na brytyjskie Indie ${ }^{67}$. Pod patronatem Niemiec doszło do zawarcia porozumienia gruzińsko-tureckiego ${ }^{68}$ i już w ten sposób Gruzja znalazła się pod faktycznym protektoratem Niemiec. Aby móc ten protektorat sformalizować, Gruzja musiała ogłosić niepodległość, co nastąpiło 26 maja 1918 r. Rada Narodowa Gruzji proklamowała wówczas Akt Niepodległości Gruzji. i tegoż dnia podpisała z Niemcami porozumienie międzypaństwowe ${ }^{69}$. Tym samym tego dnia przestała istnieć ZDFR. Do Gruzji wkroczyły wojska niemieckie; zaczęła się okupacja Gruzji przez Niemcy.

W dwa dni później (28.05.1918 r.) swoje powstanie jako niepodległe republiki proklamowały: Demokratyczna Republika Armenii oraz Demokratyczna Republika Azerbejdżanu.

Krótka niepodległość Armenii, w ramach federacji (ZDFR), była dramatyczna za sprawą dalszego posuwania się - w ciężkich walkach - wojsk tureckich. Już 4 czerwca 1918 r. Turcja wymusiła na wszystkich trzech państwach powstałych w wyniku rozpadu Zakaukaskiej Federacyjnej Republiki Demokratycznej podpisanie traktatu o pokoju i przyjaźni. Gruzja straciła dwa powiaty, ale Armenia została zredukowana do symbolicznej wręcz wielkości zaledwie 6,5 tys. $\mathrm{km}^{2}$ i tylko sąsiedzi z Azerbejdżanu mogli czuć się usatysfacjonowani, bowiem nie tylko nie ponieśli strat terytorialnych, ale nadto uzyskali zapewnienie o pomocy wojskowej w celu odzyskiwania dalszych terytoriów, a konkretnie komunistycznego Baku oraz Karabachu, faktycznie pozostającego pod władzą ormiańskich sił samoobrony. Żaden z trzech krajów nie uzyskał w traktacie formalnego uznania niepodległości, chociaż samo zawarcie takiego traktatu de facto nim było. Formalne uznanie Azerbejdżanu oraz Armenii nastąpiło dopiero w końcu września 1918 r., kiedy wojna światowa się kończyła.

Pokój (04.06.1918 r.) zawarty między Turcją a oddzielnie Armenią, Gruzją i Azerbejdżanem był tragiczny dla dwóch republik, a zwłaszcza Armenii: pokój

${ }^{66}$ T. Świętochowski, Azerbejdżan, Warszawa 2006, s. 66; T. Świętochowski, Azerbejdżan i Rosja. Kolonializm, islam, narodowość w podzielonym kraju, Warszawa 1998, s. 84.

${ }^{67}$ R. Pipes, Czerwone imperium..., s. 196; zob. też T. Świętochowski, Russian Azerbaijan, 1905-1920: The Shaping of a National Identity in a Muslim Community, Cambridge 1985, s. 127.

${ }^{68} \mathrm{Za}$ cenę podziału Adżarii oraz Meschetii i Dżawachetii, których południowe części otrzymała Turcja, ta ostatnia wstrzymała działania wojenne przeciwko Gruzji. Gruzja zatrzymała części północne oraz okręg batumski. A. Furier, op.cit., s. 135-136.

${ }^{69}$ A. Furier, op.cit., s. 131; T. Świętochowski, Russian Azerbaijan..., s. 127. 
przesuwał granice z Turcją bardziej na wschód aniżeli te sprzed 1878 r., przyznając Turcji część terenów zdobytych przez Rosję na Persji w 1828 r., Armenia niemal przestawała istnieć, gdyż pokój odrywał od niej nie tylko całą Armenię Zachodnią, lecz także m.in. południowe części okręgu Erewań, większą część okręgu Nachiczewań, ważną linię kolejową Aleksandropol-Dżulfa, zachodnią część okręgu Aleksandropol ${ }^{70} \mathrm{i}$ inne. Ponadto strona armeńska wyraziła zgodę na przemarsz wojsk tureckich przez terytorium Armenii do Azerbejdżanu, a konkretnie w kierunku Baku. Pokój wywołał wśród Ormian głębokie oburzenie, i to niezależnie od opcji politycznych.

Turcja zawarła w tym czasie z Azerbejdżanem i z Republikę Górską Północnego Kaukazu ${ }^{71}$ porozumienie w sprawie stref wpływów na muzułmańskich terenach Kaukazu ${ }^{72}$. W ten sposób przywódcy państwa - młodoturcy kontynuowali orientację panturkizmu, czyli połączenia z Turkami w jednym państwie wszystkich ludów pochodzenia turkskiego zaludniających wielki kraj - Turan: ludów Krymu, części Kaukazu wraz z Baku, Powołża, Turkiestanu, Chiwy, Buchary, perskiego Azerbejdżanu ${ }^{73}$. Jednocześnie ujawniło się podejrzewane przez sąsiadów od czasu obalenia Rządu Tymczasowego azerbejdżańskie (musawatystów) sprzyjanie Turcji. Azerowie bardziej liczyli na pomoc muzułmańskiej Turcji w toku tworzenia swojego państwa niż myśleli o obronie przed turecką inwazją. Widmo tureckiej kontroli nad Kaukazem Północnym oraz Azerbejdżanem musiało być dla Ormian i Gruzinów przerażające, bo było to widmo turkmeńskiego okrążenia, odcięcia od świata, a nawet - jeśli pamiętać o losie Ormian w 1915 r. - biologicznego wyniszczenia.

Stale trzeba pamiętać, że jest to wiosna i lato 1918 r., że jeszcze trwa wojna światowa, że jest po traktacie brzeskim, który dawał Niemcom możliwość wejścia na Kaukaz. Jak wspomniano, skorzystali z tego Gruzini, zaś efektem była niemiecka okupacja Gruzji i jej gospodarcza eksploatacja, ale przecież Niemcy wkrótce przegrają wojnę. Nasuwają się skojarzenia z bolszewickim traktatem brzeskim. Ormianie próbowali postąpić podobnie, ale Niemcy nie byli zainteresowani okupowaniem wynędzniałego, pełnego głodujących mieszkańców kraju, jakim była przeludniona uciekinierami i wyniszczona wojną Armenia. Gruzję można było

70 J. Reychman, op.cit., s 286; M. Zakrzewska-Dubasowa, op.cit., s. 233; P. Olszewski, Geopolityczne znaczenie Kaukazu Południowego po I wojnie światowej, „Przegląd Geopolityczny” 2011, t. 4, s. 77; R.G. Hovannisian, Armenia on the Road to Independence 1918, Berkeley 1967, s. $192-198$.

${ }^{71}$ Republika Górska Północnego Kaukazu (03.1917-06.1920 r.): państwo na wschodnich terenach Kaukazu Północnego, obejmujące w przybliżeniu tereny Czeczenii, Dagestanu, Inguszetii, Północnej Osetii i Kabardyno-Bałkarii, wówczas okresowo z udziałem Abchazji.

${ }_{72}$ J. Reychman, op.cit., s. 286; zob. też R. Pipes, Czerwone imperium ..., s. 196.

73 J. Pajewski, op.cit., s. 727. 
eksploatować, a do Armenii trzeba by było dokładać. Ormianie żadnego wsparcia więc nie mieli, a wokół śmiertelnie niebezpiecznych wrogów, przy których Rosjanie musieli się wydawać sprzymierzeńcami, przynajmniej zgodnie z zasadą, że „wróg mojego wroga jest moim przyjacielem”. W każdym razie rok 1918 ujawnił różnice interesów i skrajne niekiedy rozbieżności orientacji w polityce międzynarodowej krajów zakaukaskich. Nie może dziwić, że tragicznie doświadczeni i pozbawieni sojuszników Ormianie po zakończeniu działań w I wojnie światowej będą szukali protektoratu Stanów Zjednoczonych Ameryki, ale i tutaj nie doczekają się wsparcia.

20 września 1918 r. rząd radziecki oświadczył, że traktat brzeski w części odnoszącej się do Turcji uważa za nieobowiązujący ${ }^{74}$. Dla Turcji to był już koniec wojny: 9 października upadł rząd młodoturecki, a 30 października 1918 r. Turcja podpisała rozejm w Mudros ${ }^{75}$.

\section{KONIEC WOJNY, ALE NIE KONIEC WALK. MEANDRY DYPLOMACJI}

Pierwsza wojna światowa się skończyła, ale nie skończyła się wewnętrzna wojna w byłym imperium carów. Siły zbrojne Niemiec i Turcji opuściły Zakaukazie, natomiast z ramienia zwycięskiej Ententy pojawily się nadzorujące wykonanie rozejmu z 11 listopada 1918 r. wojskowe misje zwycięzców, głównie Brytyjczyków. Wszyscy, ale zwłaszcza Brytyjczycy i Francuzi, zainteresowani byli wynikiem rozwoju sytuacji w wielkiej Rosji, przy czym - jak wiadomo - rządy te nie uznawały władzy bolszewików, natomiast udzielały poparcia „białym”, a w tym momencie głową państwa rosyjskiego z tytułem Wielkorządcy Rosji był Aleksander Kołczak ${ }^{76}$, co alianci uznawali. Jak wiadomo, żaden z „białych” generałów

${ }^{74}$ J. Reychman, op.cit., s. 288; P. Olszewski, Polityka bolszewików wobec niepodległej Gruzji w latach 1918-1921, „Dzieje Najnowsze” 1997, t. 29, z. 3, s. 10; zob. też W. Morawski, S. Szawłowska, op.cit., s. 186.

75 German History in Documents and Images. Mudros Agreement: Armistice with Turkey (October 30, 1918). Vol. 6, Weimar 1918/19-1933.

${ }^{76}$ Aleksandr Wasiljewicz Kołczak, 1873-1920, pochodził z Tatarów krymskich, ale urodził się koło Petersburga, ukończył Korpus Kadetów; badacz polarny oraz syberyjski i autor prac na ten temat; w czasie wojny rosyjsko-japońskiej ranny w obronie Portu Artura; w czasie I wojny światowej dowodził marynarką wojenną na Bałtyku i Morzu Czarnym; od 1917 r. admirał; od 18.11.1918 r. Wielkorządca Rosji; zorganizował armię, która zajęła znaczną część Syberii i Ural i dotarła (03.1919 r.) do Wołgi; zamiast koordynacji działań z Denikinem Kołczak chciał pierwszy zająć Moskwę i poniósł klęskę od Armii Czerwonej; 06.01.1920 r. zrzekł się godności na rzecz Denikina; oddał się w ręce żołnierzy Korpusu Czechosłowackiego, a ci wydali go bolszewikom; rozstrzelany 07.02.1920 r. w Irkucku. WEP XIV, s. 160; Leksykon historii świata: Rosja ..., op.cit., s. 134; G. Przebinda, J. Smaga, Kto jest kim w Rosji po 1917 roku. Leksykon, Kraków 2000, s. 139; Leksykon historii powszechnej..., s. 211; W. Morawski, S. Szawłowska, op.cit., s. 182 i n. 
nie dopuszczał innej myśli niż o odbudowie Rosji w granicach nieuszczuplonych w stosunku do stanu sprzed 1914 r., a najbardziej bezkompromisowym był właśnie Kołczak. Lojalni wobec Wielkorządcy Rosji zachodni alianci byli więc negatywnie ustosunkowani do tworzenia na Zakaukaziu niepodległej Armenii.

Późną wiosną 1919 r. Denikin ruszył przez Republikę Górską Północnego $\mathrm{Kaukazu}^{77}$ w kierunku portów na Morzu Kaspijskim ${ }^{78}$, m.in. rozbijając Republikę Górską. Cztery republiki - także Republika Górska - próbowały jeszcze skoordynować swoje działania, do czego skłoniło je zagrożenie ze strony SZPR. Sojuszu wojskowego czterech republik nie udało się jednak zrealizować na skutek oporu Ormian, którzy jako warunek przystąpienia do niego stawiali wspólną obronę także przeciwko Turcji, na co z kolei nie zgadzali się pozostali negocjatorzy ${ }^{79}$. Doszło do zawarcia sojuszu obronnego tylko między Gruzją i Azerbejdżanem, z wyraźnym wskazaniem obrony przed SZPR Denikina jako celu. Azerbejdżan, Gruzja i Republika Górska wydały wspólne oświadczenie i złożyły prośbę do Rady Najwyższej Sprzymierzonych, by ta wpłynęła na Denikina, wszak utrzymywanego i politycznie wspieranego przez Sprzymierzonych, aby ten usunął się z zajętych terenów i szanował prawa republik kaukaskich ${ }^{80}$. Bez rezultatu.

Warto zauważyć, że najbardziej narażona i najbardziej osamotniona Armenia właśnie w Denikinie i Rosji pokładała pewne nadzieje i od Denikina otrzymywała pewne wsparcie w zaopatrzeniu wojskowym; zawarła w tym zakresie porozumienie z SZPR.

Kilkanaście pierwszych miesięcy po rozejmie (11.11.1918 r.) kończącym pierwszą wojnę światową przyniosło sukcesy bolszewikom w dziele imperialnego odbudowywania Rosji bolszewickiej, zwłaszcza w Europie, na szczególnie ważnym kierunku, jakim była przede wszystkim Ukraina. Bolszewicy byli szybsi w reakcji na wycofywanie się wojsk niemieckich. W kwietniu 1919 r. Armia Czerwona dotarła do Zbrucza, dawnej granicy Rosji z Austro-Węgrami. Również na południu Ukrainy Armia Czerwona zdobyła Odessę, Symferopol, Sewastopol. Zapowiadało się natomiast, że druga połowa roku 1919 przyniesie koniec władzy radzieckiej w całej dawnej Rosji. „Na wiosnę 1919 r. zaplanowano przeciwko Rosji Radzieckiej kombinowaną wyprawę Kołczaka-Denikina-Judenicza." ${ }^{\prime 1}$ Od wiosny z rejonu północnego Kaukazu niepowstrzymanie

77 Zob. przyp. 71.

${ }^{78}$ O skomplikowanej sytuacji na Kaukazie Północnym i działaniach SZPR Denikina zob. zwłaszcza S. Ciesielski, Rosja-Czeczenia. Dwa stulecia konfliktu, [w:] „Studia z dziejów Europy Wschodniej”, t. 2, Wrocław 2003, s. 116 i n., passim.

${ }^{79}$ W. Materski, Georgia..., s. 125.

${ }^{80}$ Ibidem.

81 J. Stalin, Dzieła, t. 4, Warszawa 1951, s. 295. 
szły przez Ukrainę na Moskwę Siły Zbrojne Południa Rosji pod zwierzchnictwem gen. Antona Denikina. Stanowiły je: Armia Ochotnicza, Armia Dońska oraz wojsko Kozaków kubańskich ${ }^{82}$ i Armia Kaukaska gen. Piotra Wrangla ${ }^{83}$. Na północy $-\mathrm{z}$ terytorium Estonii - na czele Korpusu Północnego ofensywę rozpoczął Judenicz i zdawało się, że nic nie uratuje dla czerwonych Piotrogrodu $^{84}$. Od wschodu, zza Uralu atakował Kołczak. Poważnym zagrożeniem dla obu stron były duże siły atamana Nestora Machny ${ }^{85}$. Armia Czerwona była

${ }^{82}$ Tak oto po latach oceniał sytuację Trocki: „Kozacy tworzyli na tyłach Denikina potężną zasłonę. Wrośli w swą ziemię i trzymali się jej zębami i pazurami. Nasz atak postawił na nogi całą ludność kozacką. Trwoniliśmy czas i siły, pchając jednocześnie do szeregów białych wszystkich kozaków zdolnych do noszenia broni." L. Trocki, Moje życie. Próba autobiografii, thum. J. Barski i S. Łukomski, Warszawa 1930 [reprint 1990], s. 506.

${ }^{83}$ Piotr Nikołajewicz Wrangel, 1878-1928 w Brukseli, wywodził się z rodu pochodzenia szwedzkiego; po studiach w Instytucie Górniczym w Petersburgu zaciągną się do wojska carskiego; urlopowany z armii na 2 lata pracował jako chemik na Syberii; wrócił (1904 r.) do służby wojskowej; w 1910 r. ukończył Akademię Sztabu Generalnego; w czasie I wojny dowodził korpusem kawalerii; po bolszewickim zamachu stanu wyjechał na Krym i po utworzeniu (12.1918 r.) Sił Zbrojnych Południa Rosji (SZPR) gen. A. Denikina został wyznaczony dowódcą Ochotniczej Armii Kaukaskiej; popadł w konflikt z Denikinem na tle odmiennych koncepcji strategicznych: Wrangel uważał, że należy dążyć do połączenia sił z Kołczakiem, zaś Denikin nakazal ruszać wprost na Moskwę; 04.04.1920 r. zastąpił pokonanego Denikina na stanowisku wodza SZPR; na Krymie i w pd. Taurydzie przeprowadził reformę rolną; odstąpił od hasła „niepodzielnej Rosji” i uznał niepodległość Polski oraz suwerenność Ukrainy; ustanowił federacyjne stosunki z niezależną Gruzją także walczącą z bolszewikami; nie przewidywał jednak żadnej formy samodzielności ustrojowej dla walczących wspólnie w SZPR Kozaków dońskich, kubańskich, tereckich ani astrachańskich, ani też dla Tatarów krymskich; w czasie wojny bolszewicko-polskiej w lipcu 1920 r. rozpoczął ofensywę i zajął Zagłębie Donieckie oraz Odessę i podjął próbę opanowania Kubania; w jesieni 1920 próbował znaleźć sojuszników w walce z bolszewikami, m.in. zawrzeć sojusz militarny z Polską, ale rząd polski nie był tym zainteresowany; po utracie ponad połowy wojska ewakuował się z wojskiem i ludnością cywilną (11.1920 r.) przez Turcję do Królestwa Serbów, Chorwatów i Słoweńców; osiadł (1927 r.) w Brukseli; działał wśród emigracji rosyjskiej; oficjalnie zmarł na gruźlicę, ale istnieje przypuszczenie, że został otruty przez służby specjalne ZSRR; pochowany w cerkwi w Belgradzie. A. Jach, [w:] Encyklopedia Biatych Plam, t. XVIII, s. 171-172; G. Przebinda, J. Smaga, op.cit., s. 319-320; zob. też Leksykon historii świata: Rosja ..., op.cit., s. 287; Leksykon historii świata, red. A. Bartnicki..., s. 518-519; Leksykon historii powszechnej..., s. 485.

${ }^{84}$ Trocki twierdzi, że ,zdaniem Lenina, nie pozostawało nic innego, jak tylko oddać Piotrogród i skrócić front." i że to Trocki z pomocą Stalina (!) wyperswadowali taką myśl Leninowi. L. Trocki, Moje życie..., s. 471.

${ }^{85}$ Nestor Machno, 1889-1934 w Paryżu, anarchista, przywódca partyzantki ludowej na Ukrainie; pochodził z biednej rodziny chłopskiej z rejonu Jekaterynosławia; za udział w zamachu na oficera policji skazany na dożywotnie więzienie; zwolniony w wyniku amnestii po rewolucji lutowej 1917 wrócił w rodzinne strony i stworzył zbrojną bandę, która grabiła okoliczne dwory i rozdawała dobra biednym chłopom; podjął działania zbrojne przeciwko wojskom austriackim oraz siłom Skoropadśkiego, a następnie przeciwko Dyrektoriatowi URL; na dużym obszarze opanowanym przez siły Machny realizował anarchistyczny model niezależnego państewka opartego o komuny wiejskie; jego hasło to ,jesteśmy za bolszewikami, ale przeciw komunistom”; miał ogromny talent i instynkt 
bliska całkowitego załamania ${ }^{86}$. Już w końcu czerwca Siły Zbrojne Południa Rosji wkroczyły do Charkowa i Carycyna (później Stalingrad, obecnie Wołgograd); Kijów oraz Odessa padły tego samego dnia (23.08.1919 r.), kilka dni później Połtawa; padł Kursk (20.09.1919 r.), później Czernihów, Woroneż zdobyty przez Kozaków dońskich, a 13 października 1919 r. Armia Ochotnicza zdobyła Orzeł i natychmiast ruszyła w pościg za cofającymi się jednostkami Armii Czerwonej. W najwyższym stopniu zagrożona była przemysłowa Tuła, a „utrata Tuły byłaby dla [bolszewików] katastrofą, gdyż znaczyłaby stratę najważniejszej fabryki karabinów i amunicji [...], utrata której byłaby groźniejsza w skutkach od utraty Moskwy." ${ }^{87}$ Dla bolszewików nie byłoby ratunku, ale - jak wiadomo wszyscy „biali” generałowie szli z hasłami odbudowy dawnej niepodzielnej, nieuszczuplonej Rosji, bez koncesji na rzecz narodów. Program społeczny oraz ustrojowy niesiony przez wojska Denikina był zdecydowanie kontrrewolucyjny. Jesienią 1919 r. zreorganizowana i przegrupowana Armia Czerwona ruszyła (10.10.1919 r.) do kontrofensywy, która była już tylko jednym ciągiem sukcesów militarnych.

W Demokratycznej Republice Armenii władzę ustawodawczą formalnie sprawował osiemdziesięcioosobowy parlament - Rada Narodowa, a faktycznie krajem rządziła jedyna licząca się partia polityczna, centrolewicowa, dasznacy. Dasznacy wysłali do Wersalu na konferencję pokojową swoich nieoficjalnych obserwatorów z misją wyjednania rozwiązania kwestii armeńskiej przez udzielenie mandatu na Armenię Stanom Zjednoczonym Ameryki. Pomysł spotkał się z przychylnym przyjęciem liberała prezydenta Wilsona i USA otrzymały (14.05.1919 r.) ten mandat; nawet podpisane zostało (30.06.1919 r.) porozumienie między USA a Demokratyczną Republiką Armenii w tej sprawie, ale w końcu Stany Zjednoczone nie ratyfikowały traktatu wersalskiego, zaś do Armenii przybyła (w końcu roku

dowódcy dużych formacji wojskowo-partyzanckich; jego pomysłem było zastosowanie taczanki ; w 1919 współpracował z Armią Czerwoną przeciwko siłom Denikina, któremu zadał druzgocące ciosy; okresowo walczył z lokalnymi władzami bolszewickimi; jego siły przyjęte w lutym $1919 \mathrm{r}$. do Armii Czerwonej szacować można nawet na blisko 100 tysięcy ludzi; odmówił, gdy bolszewicy próbowali wysłać go na front polski; po pokonaniu Wrangla bolszewicy zaatakowali i pochwycili sztab oraz dużą liczbę żołnierzy Machny i w większości ich wymordowali; Machno wymknął się z obławy i przez Rumunię, Polskę, Niemcy dotarł do Paryża, gdzie pracował jako prosty robotnik, rozpił się, zmarł w biedzie na gruźlicę. W. Roszkowski, [w:] Słownik biograficzny Europy Środkowo-Wschodniej, red. W. Roszkowski i J. Kofman, Warszawa 2004, s. 766-767; W. Serczyk, Historia Ukrainy..., s. 275; G. Przebinda, J. Smaga, op.cit., s. 174-175; WEP XVI 369; Leksykon historii świata: Rosja, op.cit., s. 161; Leksykon historii powszechnej..., s. 254; Leksykon historii świata, red. A. Bartnicki..., s. 253.

${ }^{86}$ G. Swain, Wojna domowa w Rosji, thum. Z. Simbierowicz, Warszawa 2007, s. 148, passim.

${ }^{87}$ L. Trocki, Moje życie..., s. 506. 
1919) delegacja amerykańska z generałem Jamesem G. Harbordem dla zbadania celowości przyjęcia przez USA mandatu nad Armenią. Opinia misji amerykańskiej była negatywna: większość mieszkańców orientuje się na ponowny związek z Rosją jako jedyny sposób zapewnienia sobie bezpieczeństwa od sąsiadów oraz stabilizacji ekonomicznej wynędzniałego kraju. Stany Zjednoczone mandatu nie przyjęły ${ }^{88}$. Wysyłały (1919-1920) tylko pomoc charytatywną (American Relief Administration), dzięki której tysiące ludzi uniknęły śmierci głodowej. Amerykanie natomiast odrzucili prośbę Armenii o udzielenie pomocy wojskowej.

Zwycięskie w wojnie światowej mocarstwa pozostawiły Kaukaz w strefie wpływów angielskich; Tbilisi zostało obrane na siedzibę Wysokiego Komisarza. Wielka Brytania oczekiwała w Rosji zwycięstwa „białych”, a na Zakaukaziu zwłaszcza zabezpieczenia swoich interesów w rejonie Morza Kaspijskiego (Baku), względnie blisko Afganistanu i Indii. To oczywiście budziło angielskie zainteresowanie ustabilizowanym i silnym Azerbejdżanem. Muzułmański Azerbejdżan w zamyśle Anglików miał też osłabić Turcję. Należy dodać, że w 1919 r. do Wersalu przybyły trzy misje trzech republik Zakaukazia w poszukiwaniu wsparcia, ale od aliantów usłyszeli, że Ententa popiera „białych” $i$ ich sprawy muszą zaczekać do rozwiązania globalnego problemu rosyjskiego. Szczególnie dobitnie artykułował to brytyjski minister spraw zagranicznych lord Curzon ${ }^{89}$, a Zakaukazie to wszak strefa wpływów brytyjskich, więc zdanie takie było w praktyce równoznaczne z decyzją Ententy. W styczniu 1920 r. główne mocarstwa Ententy - Rada Najwyższa Sprzymierzonych - uznały de facto republiki zakaukaskie ${ }^{90}$.

Kiedy upadł rząd młodoturecki (09.10.1918 r.), a Turcja podpisała rozejm w Mudros (30.10), w miejsce wycofywanych wojsk tureckich (liczni zawodowi wojskowi tureccy otrzymali prawo indywidualnego wstępowania do wojska azerskiego) wkraczali zwycięscy alianci głównie celem zabezpieczenia Baku oraz zakaukaskich linii kolejowych, przede wszystkim jednostki brytyjskie ${ }^{91}$.

88 M. Zakrzewska-Dubasowa, op.cit., s. 235; R. Pipes, Czerwone imperium..., s. 211.

89 R. Pipes, Czerwone imperium..., s. 219.

90 W. Materski, Georgia..., s. 158-160, tamże szczegółowo interesujący przebieg wydarzeń; zob. też idem, Gruzja..., s. 92; T. Świętochowski, Azerbejdżan..., s. 84.

91 Warto wyjaśnić, że po obaleniu Komuny Bakijskiej (głównie siłami mienszewików i Ormian) nowy, antybolszewicki ośrodek władzy zwrócił się do Brytyjczyków o pomoc zbrojną, a to wobec groźby nadciągających wojsk turecko-azerbejdżańskich. Wówczas to niewielki angielski oddział przybył do Baku przez Morze Kaspijskie w sierpniu 1918 r., ale już 14.09.1918 r. pospiesznie ewakuował się wobec zbliżających się wojsk turecko-azerskich, które też zajęły miasto i wówczas doszło do rzezi Ormian. Po zakończeniu wojny wojska brytyjskie wylądowały w Baku 17.11.1918 r., a w Batumi 23.12.1918 r. Brytyjczycy zaczęli się wycofywać z Zakaukazia już w pół roku później, latem 1919, z wyjątkiem portu w Batumi. Wiązało się to z postępami ofensywy Denikina. Zob. zwłaszcza P. Olszewski, Geopolityczne znaczenie Kaukazu Południowego po I wojnie światowej, „Przegląd Geopolityczny” 2011, t. 4, s. 77-78. 
Głównodowodzący gen. William M. Thomson przybył z polityczną misją przywrócenia Zakaukazia Rosji „białej”, ale jednak niektórym Anglikom majaczyła wizja utworzenia rozległego państwa szyitów (przypomnieć warto: szyici dominowali w Persji, zaś sunnici w Turcji), które oddzielałoby Rosję, Turcję i Persję, w której z dawna interesy i wpływy mieli Brytyjczycy (zob. wyżej o porozumieniu brytyjsko-rosyjskim z 1907 r.). Rezultatem było faktyczne przejęcie przez Brytyjczyków roli mocarstwa nadzorującego interesy Azerbejdżanu w jakże zaognionych sporach Zakaukazia, zaś ofiarą padli Ormianie. Kiedy Turcja po Mudros wycofała swoje wojska z Górnego Karabachu, siły ormiańskie rozpoczęły ofensywę przeciwko wojskom azerskim, ale wówczas presję wywarli Brytyjczycy i akcja Ormian została zatrzymana (w grudniu 1918) ${ }^{92}$. „Wzdłuż całej granicy nie było odcinka, co do którego Armenia i Azerbejdżan nie zgłaszałyby wzajemnych pretensji" ${ }^{93}$ i angielski generał spory rozstrzygał na korzyść Azerów, m.in. cały Górski Karabach wraz z przyległym powiatem zangezurskim oddał pod tymczasową administrację azerbejdżańską, jak również dokonywał licznych innych posunięć i dopuszczał się wypowiedzi politycznie wielce niekorzystnych dla interesów ormiańskich, a korzystnych dla azerbejdżańskich. Decyzja o oddaniu Azerom Karabachu ostatecznie została potwierdzona 3 kwietnia 1919 r., a w trzy tygodnie później (24.04.1919 r.) Anglicy przekazali władzę nad Nachiczewaniem Armenii ${ }^{94}$, co wyglądało jak próba zadośćuczynienia, ale skutki w postaci nieustających walk przemieszanej ludności trwają do dzisiaj. Nieszczęściem narodów Zakaukazia było i jest daleko idące przemieszanie etniczne. Długotrwała przynależność regionu do Rosji pogłębiała zatarcie granic narodowych. W zasadzie wszyscy mieli pretensje terytorialne do wszystkich. Po wyjściu wojsk tureckich z Zakaukazia, zaraz po zakończeniu I wojny światowej, w grudniu 1918 r. doszło do lokalnej wojny między Gruzją a Armenią o rejon Borczało, który pod naciskiem brytyjskim został między walczących podzielony i zapanował spokój, ale część przypadającą Armenii Gruzja zajęła zaraz po upadku niepodległej Armenii w 1920 r. W 1919 i 1920 r. trwały walki armeńsko-azerbejdżańskie o Karabach, Nachiczewań oraz Zangezur. Latem 1919 r., kiedy wojska brytyjskie po krótkim pobycie opuściły Baku, Demokratyczna Republika Azerbejdżanu zawarła z Demokratyczną Republiką Gruzji sojusz wojskowy (16.06.1919 r.), który w Armenii odczytywano jako wymierzony w nią, a także w Denikina. Osamotniona Demokratyczna Republika Armenii podjęła współpracę z popieranymi przez Ententę Siłami Zbrojnymi

92 R.G. Hovannisian, The Republic of Armenia, t. 1: The First Year 1918-1919, Berkeley 1971, s. 86 i n.

${ }_{93}$ Bliżej zob. T. Świętochowski, Azerbejdżan..., s. 72.

${ }_{94}$ P. Olszewski, Geopolityczne znaczenie Kaukazu..., s. 82. 
Południa Rosji, czyli z Denikinem, który wspierał Republikę finansowo oraz uzbrojeniem. To już było nie tylko rozejście się dróg trzech narodów Zakaukazia, ale ustawienie się w obozach sobie wrogich.

Za zgodą Brytyjczyków, po zakończeniu wojny światowej, na przełomie 1918 i 1919 r. Armenia zajęła część Anatolii Wschodniej. Niedawni uchodźcy ormiańscy przed tureckimi pogromami, na ogół nędzarze, zaczęli wracać do domu. W maju 1919 r. Demokratyczna Republika Armenii oficjalnie ogłosiła aneksję tureckiej Armenii ${ }^{95}$. Od października 1919 r. Armia Radziecka gromiła siły Denikina, którego armie topniały jak śnieg na słońcu. Wkrótce Kołczak zostanie rozstrzelany, a Denikin odpłynie z Krymu na angielskim okręcie. Separatyści ukraińscy pokonani przez czerwonych. Jeszcze tylko Polacy pozostali gotowi stawić czoła rosyjskiemu imperializmowi. Od jesieni 1919 r., równolegle do sukcesów wojskowych Armii Radzieckiej, nasilała się aktywność komunistów na terenie Zakaukazia, m.in. w Armenii. Próba komunistycznego przewrotu w maju 1920 r., kiedy to Wojenno-Rewolucyjny Komitet Armenii proklamował utworzenie w Armenii władzy radzieckiej i zrabował amerykańskie magazyny żywnościowe z pomocą dla ludności, próba ta została przez dasznaków krwawo stłumiona. Następna próba będzie lepiej wsparta z Moskwy we współdziałaniu z Turcją.

\section{TRAKTATY I ZAMIARY}

Na koniec pierwszej wojny państw Ententy z Turcją trzeba spoglądać oczywiście od separatystycznego traktatu brzeskiego z 3 marca 1918 r., który wszak zlikwidował wschodniego sojusznika Zachodu. Rosja zaś szachowała od wschodu imperium osmańskie i jedynie na tym froncie odnosiła sukcesy. Traktat brzeski Rosji z państwami centralnymi, jak wiadomo, przekazywał im blisko 1 milion $\mathrm{km}^{2}$. Pomijając tutaj inne nad wyraz ważne postanowienia traktatu, zwłaszcza na arenie militarnej i politycznej Europy, trzeba przypomnieć, że Rosja miała wycofać swoje wojska nie tylko z terenów państwa tureckiego zajętych w czasie wojny, lecz także z okręgów Kars, Ardahan i Batumi, które zostały oderwane od Turcji i przyłączone do Rosji na mocy postanowień kongresu berlińskiego z 1878 r. Strona turecka interpretowała odpowiednie postanowienia w sposób dla siebie korzystniejszy, mianowicie w ten sposób, że tereny te mają wrócić niezwłocznie do Turcji; Enver Pasza niezwłocznie wydał wojskom rozkaz wymarszu i zajęcia wspomnianych terytoriów. Tymczasem było inaczej: traktat brzeski przewidywał $\mathrm{w}$ tej sprawie porozumienie Turcji z sąsiadami oraz niesprecyzowany

95 R. Pipes, Czerwone imperium..., s. 212. 
udział miejscowej ludności w decyzjach ${ }^{96}$. Wówczas jednak na Zakaukaziu - jak o tym była mowa - tworzyły się trzy państwa narodowe: przejściowo powstała (22.04.1918 r.) Zakaukaska Federacyjna Republika Demokratyczna, a w kilka tygodni później powstały trzy odrębne państwa. Wobec posuwania się wojsk tureckich trzy republiki zakaukaskie znalazły się via facti w stanie wojny z Turcją, wojny, którą zarówno Gruzja, jak i najbardziej narażona i zmasakrowana Armenia przegrywały. Wtedy jednak brytyjska ofensywa w Syrii oraz klęska w Macedonii (15.09.1918 r.) bułgarskich sojuszników Turcji, zmieniły stan rzeczy. Sytuację wykorzystali też po mistrzowsku bolszewicy i ludowy komisarz spraw zagranicznych Gieorgij Cziczerin ${ }^{97}$ wystosował (20.09.1918 r.) notę do rządu tureckiego z oświadczeniem, że wobec naruszenia przez Turcję traktatu brzeskiego rząd radziecki uważa, że traktat ten w odniesieniu do Turcji przestał obowiązywać ${ }^{98}$. Niesnaski imperialistyczne między sojusznikami - Niemcami i Turcją - doprowadziły do uzupełnienia traktatu brzeskiego rosyjsko-niemieckim porozumieniem ${ }^{99}$ (27.08.1918 r.), m.in. pozwalającym Niemcom na uznanie Gruzji oraz ustana-

${ }^{96}$ Art. 4 traktatu: „Rosja zrobi wszystko ze swej strony, by zapewnić natychmiastową ewakuację prowincyj wschodniej Anatolii i jej pełnoprawnego powrotu do Turcji. Dystrykty Erdehan, Kars i Batumi zostaną w podobny sposób i bezzwłocznie opuszczone przez rosyjskie wojska. Rosja nie będzie się wtrącać w reorganizację narodowych i międzynarodowych stosunków tych dystryktów, ale pozostawi ludności tych dystryktów sprawę przeprowadzenia tej reorganizacji w zgodzie z sąsiadującymi Państwami, w szczególności z Turcją". Tekst porozumienia pokojowego z Brześcia Litewskiego 3 marca 1918, http://tnke.home.pl/armianiemiecka/Dokument/1918b.htm [dostęp: 28.10.2017].

${ }^{97}$ Gieorgij Wasiljewicz Cziczerin, 1872-1936, ludowy komisarz spraw zagranicznych RSFRR i ZSRR, pochodził z rodziny arystokratycznej, syn byłego dyplomaty, krewny prawnika i filozofa Borysa Cziczerina, na emigracji 1904-18 nawiązał kontakt z socjaldemokratami niemieckimi i z Leninem, któremu pomógł w powrocie do Rosji w 1917 r., od 1905 r. w SDPRR, najpierw mienszewik, po powrocie do Rosji w partii bolszewików, od 24.02.1918 r. przewodniczył delegacji radzieckiej na rokowaniach brzeskich i podpisał traktat brzeski (03.03.1918 r.); w marcu 1918 r. najpierw p.o., a od 30.05.1918 r. komisarz ludowy spraw zagranicznych RSFRR, potem ZSRR; m.in. uczestnik rozmów pokojowych z krajami bałtyckimi, Finlandią, Polską, podpisał traktaty o pokoju i współpracy z Turcją i Persją, z Niemcami w Rapallo i in.; uczestniczył w planowaniu wschodniego frontu „rewolucji światowej”, w szczególności przez opanowanie Persji oraz Konstantynopola; profesjonalny dyplomata i nienagannych manierach i znajomości języków. Ciężko chory oraz niewybrednie atakowany przez swojego późniejszego następcę Litwinowa, poprosił o dymisję, która została przyjęta 1930 r.; zmarł w Moskwie. Л. И. Трофимова, Вступительная статя, [w:] Г.В. Чичерин, Стати и речи по вопросам международной политики, составитель Л.И. Трофимова, Москва 1961, s. 3-21; G. Przebinda, J. Smaga, op.cit., s. 59-61; Чичерин Георгий Васильевич, http://www. hrono.ru/biograf/bio_ch/chicherin_gv.php [dostęp: 07.01.2018].

98 J. Pajewski, op.cit., s. 728; J. Reychman, op.cit., s. 288; P. Olszewski, Polityka bolszewików..., s. 10; W. Morawski, S. Szawłowska, op.cit., s. 186.

${ }^{99}$ Treść zob. T. Świętochowski, Russian Azerbaijan..., s. 134; zob. też W. Materski, Gruzja, op.cit., s. 72; P. Olszewski, Polityka bolszewików..., s. 10; Г.В. Чичерин, Стати и речи по вопросам международной политики..., s. 62-66. 
wiającym linię dookoła Baku, której nie wolno było (scil.: Turcji) przekroczyć. Zbliżał się koniec wojny światowej z wyraźnym kompromitującym i fatalnym terytorialnie dla Turcji wynikiem. 8 stycznia 1918 r. w orędziu do Kongresu prezydent Thomas Woodrow Wilson w dwunastym z czternastu punktów swojego powojennego programu i wizji świata powiedział: „ludności tureckiej Imperium Osmańskiego zapewniona zostanie suwerenność i bezpieczeństwo, innym narodom zamieszkującym Imperium przysługuje prawo do bezpieczeństwa i rozwoju, oraz autonomia. Dardanele zostaną otwarte dla okrętów i statków handlowych, zabezpieczone gwarancją międzynarodową".

Podyktowane Turkom na brytyjskim okręcie wojennym w Mudros warunki rozejmowe były nie tylko twarde, lecz wręcz druzgocące. Natomiast w obszarze Zakaukazia było zupełnie inaczej: wojska tureckie miały wycofać się do linii granicznej z 1914 r., a więc bez strat terytorialnych. Był to jednak na razie tylko rozejm. Zwycięscy kapitaliści przystąpili do dzielenia łupów: dwa dni po zawarciu rozejmu z Niemcami (13.11.1918 r.) wojska brytyjskie opanowały cieśniny czarnomorskie i wkroczyły do Stambułu; w kilka miesięcy później wojska greckie wylądowały w Izmirze (z zamiarem stworzenia drogą faktów dokonanych Wielkiej Grecji), zaś włoskie w południowej Anatolii. Anglicy z Francuzami ścigali się $\mathrm{w}$ zajmowaniu południowych terenów byłego imperium: m.in. Iraku, Palestyny, Syrii, krajów arabskich. Zgodnie z wizją Wilsona miała powstać Wielka Armenia (w planach było przyznanie jej sześciu prowincji byłej Turcji); powstać miał także autonomiczny ${ }^{100}$, a w przyszłości prawdopodobnie niepodległy Kurdystan ${ }^{101}$.

100 Art. 62 traktatu z Sẻvres 1920: „A Commission sitting at Constantinople and composed of three members appointed by the British, French and Italian Governments respectively shall draft within six months from the coming into force of the present Treaty a scheme of local autonomy for the predominantly Kurdish areas lying east of the Euphrates, south of the southern boundary of Armenia as it may be hereafter determined, and north of the frontier of Turkey with Syria and Mesopotamia, as defined in Article 27, II (2) and (3). If unanimity cannot be secured on any question, it will be referred by the members of the Commission to their respective Governments. The scheme shall contain full safeguards for the protection of the Assyro-Chaldeans and other racial or religious minorities within these areas, and with this object a Commission composed of British, French, Italian, Persian and Kurdish representatives shall visit the spot to examine and decide what rectifications, if any, should be made in the Turkish frontier where, under the provisions of the present Treaty, that frontier coincides with that of Persia." Art. 64 przewidywał możliwość przyznania w przyszłości pełnej niepodległości Kurdystanowi. The Treaty of Sèvres, 1920 (za: The Treaties of Peace 1919-1923, Vol. II, New York 1924) https://wwi.lib.byu.edu/index.php/Section_I,_Articles_1_-_260 [dostęp: 14.01.2018].

${ }_{101}$ Zob. m.in. Historia Kurdystanu, na portalu przedstawicielstwa w Polsce Rządu Regionalnego Kurdystanu, http://poland.gov.krd/about-kurdistan/history-of-kurdistan/?lang=pl [dostęp: 08.01.2018]. 


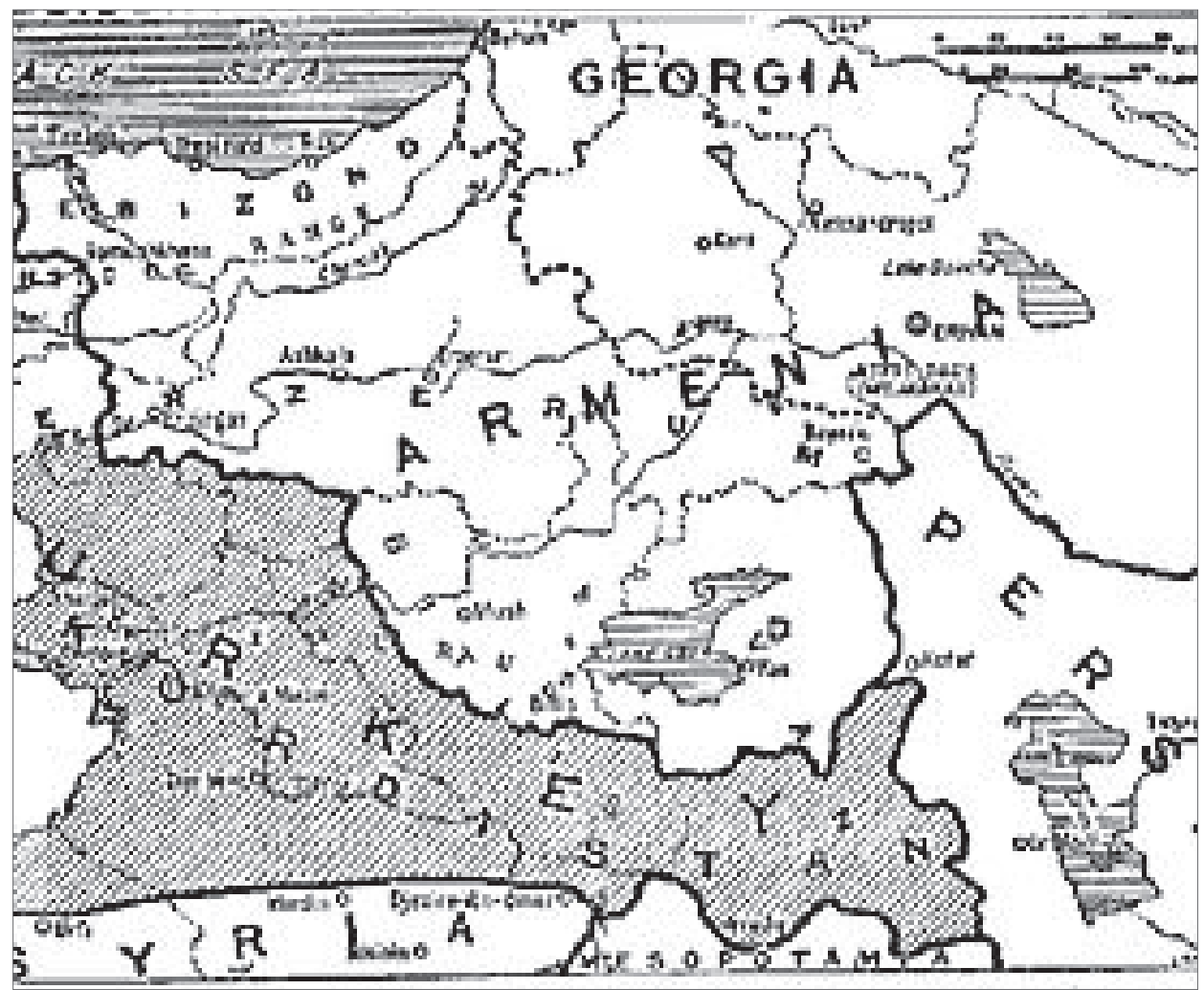

Źródło: The Treaty of Sèvres, 1920 (za: The Treaties of Peace 1919-1923, Vol. II, New York 1924.) (Compiled by Lt.-Col. Lawrence Martin, Geographer of the Institute of Politics). https://wwi.lib.byu.edu/images/2/22/Treaty_of_Sevres_President_Wilson_Armenian_Boundary.gif [dostęp: 29.10.2017]

Jak wiadomo, 10 sierpnia 1920 r. w Sẻvres pod Paryżem przedłożono Turcji warunki traktatu pokojowego; przedstawiciele tureccy go sygnowali. Na jego mocy Turcja miała utracić trzy czwarte swojego dotychczasowego terytorium. Wielka Brytania otrzymywała jako terytoria mandatowe Arabię, Mezopotamię, Palestynę oraz Mosul; Francja mandaty nad Syrią oraz Cylicją ${ }^{102}$; Grecja miała otrzymać Trację Wschodnią z Półwyspem Gallipoli oraz Smyrnę (Izmir), w której po pięciu latach miał odbyć się plebiscyt; Włochom miał przypaść ogromny obszar południowo-wschodniej Anatoli od Adalii (Antalya) do Konyi; na południu miał powstać Kurdystan cieszący się autonomią, a na wschodzie niepodległa Wielka Armenia, której ostateczne granice miały być poddane pod arbitraż pre-

${ }^{102}$ Kraina w południowo-wschodniej Azji Mniejszej (w Turcji), nadmorska (zob. mapka 1); w latach 1080-1375 ormiańskie państwo, najpierw księstwo, potem Królestwo Cylicji, znane także jako Armenia Mała albo Nowa Armenia. 
zydenta USA Wilsona ${ }^{103}$. Cieśniny planowano zdemilitaryzować i zapewnić swobodną żeglugę. Nie były to bynajmniej wszystkie ciężary nałożone na Turcję ${ }^{104}$. Tylko Rosja - oczywiście - nie miała nic otrzymać, a przecież na początku wojny carska Rosja z poważnymi szansami reflektowała na Stambuł. Zbrodniarze mieli zostać osądzeni.

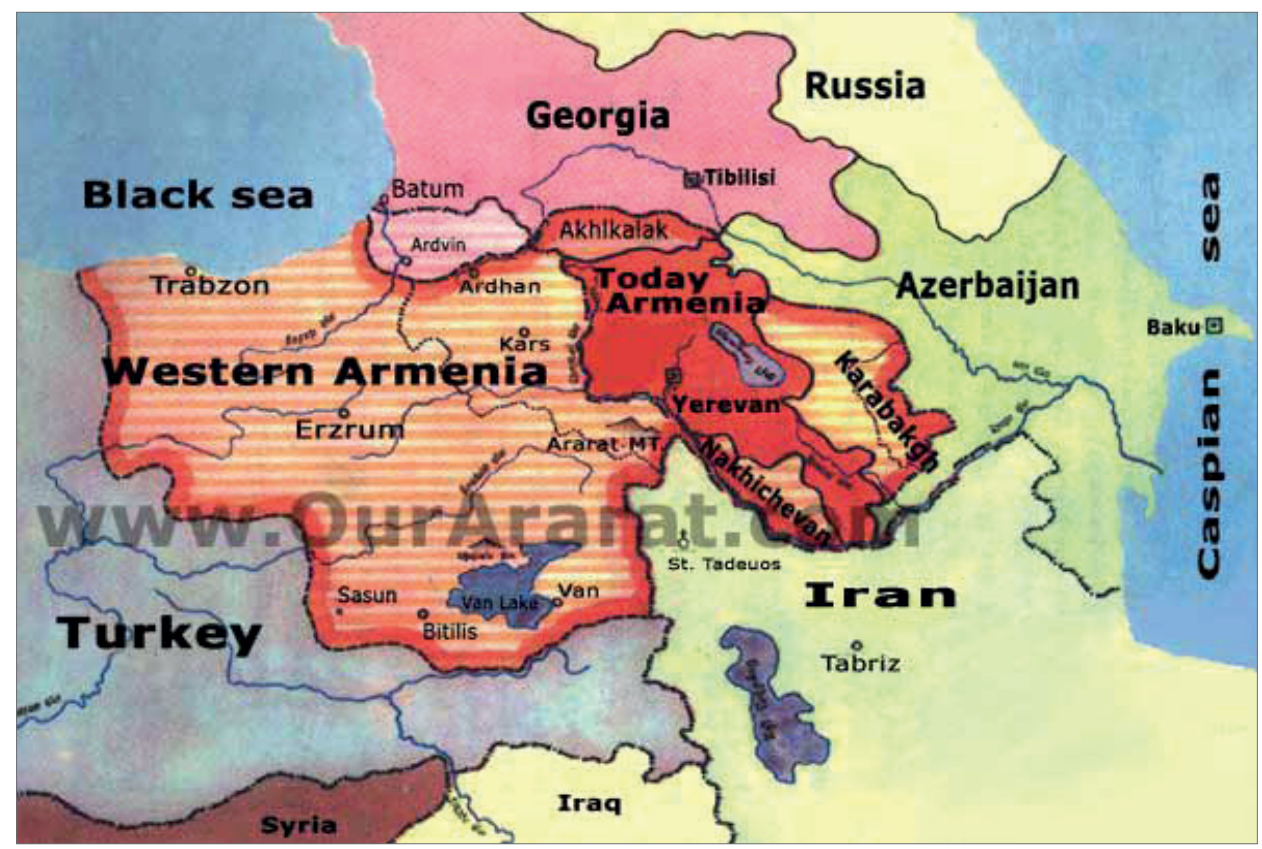

Źródło: https://unitedcats.files.wordpress.com/2010/06/wilsonian_armenia.jpg [dostęp: 03.11.2017]

Radość Ormian z ogromnych nabytków terytorialnych po traktacie w Sẻvres była jednak przedwczesna. Kemal Pasza podejmował walkę o ratowanie Turcji w dawnych granicach.

${ }^{103}$ Art. 89: „Turkey and Armenia as well as the other High Contracting Parties agree to submit to the arbitration of the President of the United States of America the question of the frontier to be fixed between Turkey and Armenia in the vilayets of Erzerum, Trebizond, Van and Bitlis, and to accept his decision thereupon, as well as any stipulations he may prescribe as to access for Armenia to the sea, and as to the demilitarisation of any portion of Turkish territory adjacent to the said frontier." The Treaty of Sèvres..., op.cit.

104 Ponadto Turcja miała utrzymywać armię nie większą niż 50 tys. żołnierzy, miała wydać aliantom niemal całą flotę; zlikwidować fortyfikacje w cieśninach. J. Reychman, op.cit., s. 291-292; M. Bankowicz, [w:] Historia polityczna świata XX wieku. 1901-1945, red. M. Bankowicz, Kraków 2004, s. 149. 
Stosunki Rosji z Turcją ${ }^{105}$ uległy zaś zmianie po powstaniu ruchu narodowowyzwoleńczego Mustafy Kemala Paszy. Ujęty w traktat z Sẻvres rozbiór Imperium Osmańskiego planowano i miano zrealizować wszak bez udziału Rosji bolszewickiej, ale przez państwa „imperialistyczne”, które dla czerwonej Rosji były wrogami. W ten sposób dwaj odwieczni wrogowie - Turcja i Rosja czerwona (ale tylko czerwona) - znalazły się jak gdyby po jednej stronie barykady. Geograficznie zaś jedynym miejscem styku było Zakaukazie i Kaukaz, toteż nic dziwnego, że jeśli miało dojść do porozumienia obu państw, to w sposób naturalny teren ten stałby się zakładnikiem i miejscem targów terytorialnych bez udziału narodów tam żyjących. „Kemal Pasza następująco sformułował strategiczne cele tureckiej polityki w odniesieniu do Zakaukazia: interes [turecki - AL] walki wyzwoleńczej wymaga zlikwidowania Armenii jako samodzielnego państwa, zmiany obecnego rządu azerbejdżańskiego na proradziecki oraz neutralności Gruzji - jedynej z trzech republik, która mogłaby pozostać nienaruszona. Azerbejdżan służyłby wówczas jako pomost między Rosją radziecką a Turcją walczącą o wyzwolenie narodowe. [...] Gdyby państwa Zakaukazia chciały pełnić funkcję bariery wobec Turcji, należałoby - twierdził - porozumieć się z bolszewikami co do wspólnej akcji przeciwko tym krajom" ${ }^{106}$. Nacjonalizm turecki kemalistów z istoty swej odrzucał turanizm, panturkizm, panislamizm, a więc idee, które mogłyby być groźne dla bolszewickiego odbudowywania byłego carskiego imperium, tym razem pod czerwonym sztandarem. To nowość w polityce na styku Europy i Azji.

Narodowowyzwoleńczy ruch kemalistów skutkował wznowieniem walk o powrót do Turcji odbieranych jej ziem, turecki atak wojskowy skierował się przede wszystkim przeciwko krajom zakaukaskim, najsłabszym z przeciwników, przy czym Azerbejdżan był wśród nich krajem sprzyjającym Turcji. Wszak to tutaj, na Zakaukaziu, kemaliści mogli najłatwiej i najszybciej osiągnąć sukcesy, które dodawałyby sił ich ruchowi. Armenia została więc wystawiona na najcięższą próbę, o czym była mowa wcześniej. Sytuacja krajów kaukaskich stała się tym bardziej dramatyczna, że kemalistowski rząd turecki bardzo zgrabnie rozegrał sprawę rosyjską. Wychodząca od Turcji propozycja nawiązania stosunków dyplomatycznych z ,czerwoną" Rosją została przez bolszewików natychmiast przyjęta; nie przeszkadzały różnice ideologiczne, gdy chodziło o imperialne interesy na Zakaukaziu. We wrześniu (23.09.1920 r.) wybuchła wojna turecko-armeńska wpisująca się w turecką walkę przeciwko rozbiorowi państwa tureckiego. Turcja zaatakowała Armenię z zaskoczenia i duże siły tureckie szybko zdobyły m.in. Kars, Ardagan, Alek-

105 Bliżej o tych wydarzeniach i kontaktach Turcji z Rosją zob. W. Materski, Georgia..., s. 172; T. Świętochowski, Russian Azerbaijan..., s. 162; J. Reychman, op.cit., s. 296; J. Pajewski, op.cit., s. 296-297; K. Kontek, Mustafa Kemal Atatürk i jego współczesny wizerunek, „Etnografia Polska”, 2011, t. 55, z. 1-2, s. 227-248.

${ }^{106}$ Cyt. za T. Świętochowskim, Azerbejdżan ..., s. 84, podkreślenie w tekście moje - AL. 
sandropol. Siły tureckie były wspomagane przez Armię Radziecką; dwa potężne państwa i odwieczni wrogowie wspólnie napadli na małą Armenię. Polakom nie może się to nie kojarzyć z paktem Ribbentrop-Mołotow. Na polecenie z Moskwy (samego Lenina, z prawdopodobnym udziałem komisarza do spraw narodowości Stalina,wszak Gruzina) złożona z weteranów i wspierana specjalnymi pociągami pancernymi bolszewicka 11. armia pod dowództwem Michaiła Tuchaczewskiego najpierw doprowadziła do opanowania przez komunistów Kaukazu Północnego, a następnie Azerbejdżanu, gdzie komuniści stanowili w uprzemysłowionym Baku pewną siłę. Data ataku bolszewickiego na Azerbejdżan (27-29.04.1920 r.) nie była przypadkowa. Kilka dni wcześniej (23.04.1920 r.) w Turcji Mustafa Kemal Pasza uzyskał pełnomocnictwa faktycznie dyktatorskie i natychmiast zaproponował czerwonej Rosji nawiązanie stosunków dyplomatycznych i walkę z ,wersalskim dyktatem" mocarstw zachodnich. Wygląda to trochę na przedłużenie I wojny światowej po stronie państw centralnych. W każdym razie kraje Kaukazu tak Południowego, jak i Północnego znalazły się między czerwoną Rosją a kemalowską Turcją. Daleko w Europie, znad Zbrucza, ruszała wówczas ofensywa polska, co skutkowało tylko odroczeniem bolszewickiej inwazji na dwa pozostałe kraje zakaukaskie; 11. armia została tymczasowo skierowana na front polski.

Kemalistowska Turcja i jej ruch narodowy - jak wiadomo - odniosły sukces. Traktat w Lozannie (1923) anulował wszystkie dotkliwe dla Turcji wcześniejsze ustalenia, w tym także terytorialne, z krzywdą Armenii.

Ponosząc klęski w wojnie ze znacznie silniejszą Turcją, Ormianie zgodzili się na wszystkie żądania tureckie, a były one nad wyraz twarde: oddanie dwóch trzecich terytorium Anatolii Wschodniej, do której rościła pretensje Armenia, zmniejszenie armii do 1500 żołnierzy, wypowiedzenie traktatu z Sẻvres. 2 grudnia 1920 r. w Aleksandropolu taki pokój podpisano. Nieprzypadkowo trzy dni wcześniej miały miejsce równocześnie dwa wydarzenia. Nikomu nieznana grupa komunistów, niepodpisanych zresztą pod dokumentem, mianując się Komitetem Rewolucyjnym Armenii, proklamowała Armenię Socjalistyczną Republiką Radziecką ${ }^{107}$. Tego samego dnia, 29 listopada 1920 r., sowiecki poseł w Erewaniu wręczył rządowi Demokratycznej Republiki Armenii ultimatum z żądaniem niezwłocznego przekazania władzy Komitetowi Wojskowo-Rewolucyjnemu Socjalistycznej Radzieckiej Republiki Armenii, który to komitet - jak stwierdzał dokument - przebywał aktualnie w Azerbejdżanie (przybył do Erewania 6 grudnia). Jednocześnie kolumny 11. armii sowieckiej przekroczyły granicę azerbejdżańsko-armeńską posuwając się w kierunku Erewania ${ }^{108}$. Dasznacy niezwłocznie przy-

107 История советской конституции. Сборник документов. 1917-1957, Москва 1957, s. $134-135$.

${ }^{108}$ R. Pipes, Czerwone imperium..., s. 234. 
jęli sowieckie ultimatum, prawdopodobnie bojąc się bardziej okupacji tureckiej (ludobójstwo przecież dobrze pamiętano) aniżeli sowieckiej Rosji. W ten sposób Turcja i Rosja - zaciekli wrogowie od zawsze - wspólnymi siłami dokonali rozbioru małej, dzielnie walczącej Armenii.

W dziewiętnaście lat później analogicznie postąpią Stalin z Hitlerem względem Polski i krajów Europy środkowo-wschodniej.

2 grudnia 1920 r. w Erewaniu podpisano układ między Republiką Armenii i RSFRR, który teoretycznie nosił charakter traktatu międzynarodowego, ale silnie wkraczał w wewnętrzne sprawy Republiki ${ }^{109}$. W dwa dni później do Erewania wkroczyły oddziały sowieckie. Układ nigdy nie był przez Rosję sowiecką przestrzegany, m.in. mimo zapewnienia o niepociąganiu wojskowych do jakiejkolwiek odpowiedzialności za wcześniejsze działania zbrojne, w krótkim czasie aresztowano i wywieziono do łagrów w Rosji około 1400 oficerów, w tym 20 generałów.

Armenia dostała się pod panowanie bolszewików, głównie moskiewskich. W efekcie wszelkie decyzje, a więc także w kwestiach zawiłych spraw granicznych zapadały w Moskwie, a tam Ludowym Komisarzem do Spraw Narodowości był Stalin. Początkowo, na żądanie azerbejdżańskiej Rady Komisarzy Ludowych, Górski Karabach decyzją Narkomnacu, wyjęto spod władzy Ormian i oddano Azerbejdżanowi, ale już wkrótce (w grudniu 1920 r.) Narimanow zdecydował się Górski Karabach oddać Armenii, gdy ta stała się również republiką socjalistyczną w ramach RSFRR. Po dalszych trzech latach sporów, już w ramach ZSRR, w 1923 r. Moskwa zdecydowała, iż Karabach wraca do Azerbejdżanu, zaś w części Karabachu zasiedlonej w większości przez Ormian tworzy się Nagorno-Karabachski Obwód Autonomiczny. Drugim szczególnie spornym obszarem azersko-ormiańskim był oczywiście Nachiczewań. Kiedy Armenia stała się radziecka, w grudniu 1920 r. na mocy traktatu między obiema republikami, Nachiczewań włączony został do Armenii. Jednak już w trzy miesiące później, gdy RSFRR prowadziła z Turcją rozmowy zakończone układem o przyjaźni tych odwiecznych wrogów, Moskwa wyraziła zgodę na życzenie Turcji, by ta miała wspólną granicę z Azerbejdżanem, co rozwiązano w ten sposób, że Nachiczewań odebrano Armenii i włączono do Azerbejdżanu; w ten sposób powstała siedemnastokilometrowa granica turecko-azerbejdżańska. Po utworzeniu ZSRR utworzono w granicach Azerbejdżańskiej SRR Nachiczewański Kraj autonomiczny, który nieco później (09.02.1924 r.) przekształcono w Nachiczewańską Autonomiczną Socjalistyczną Republikę Radziecką ${ }^{110}$.

109 Tekst zob. w: R. Pipes, Czerwone imperium..., s. 235.

110 T. Świętochowski, Azerbejdżan..., s. 96-97, z tym że trzeba tu skorygować autora: w 1924 r. nie utworzono Republiki Nachiczewańskiej jako związkowej, lecz jako autonomiczną.; zob. też T. Świętochowski, Russian Azerbaijan..., s. 162. 
Komitet Wojskowo-Rewolucyjny niezwłocznie (21.12.1920 r.) ogłosił, że wszystkie akty prawne wydane przez władzę radziecką na terenie Rosji obowiązują również w Armenii. Utworzono Radę Komisarzy Ludowych, przy czym - co oryginalne - Komitet Wojskowo-Rewolucyjny stanowił prezydium Rady. Powołano sądy ludowe. Znacjonalizowano ziemię, lasy, bogactwa naturalne, wody, kanały, przedsiębiorstwa przemysłowe, handel, banki, wprowadzono do obiegu pieniądz RSFRR; rozdzielono kościół od państwa, zabroniono nauki religii w szkołach ${ }^{111}$.

Już w styczniu 1921 r. dasznacy rozpoczęli powstanie, mimo silnych jednostek, także pociągów pancernych, przeciwnika - Armii Radzieckiej, siły dasznaków, przy wsparciu miejscowej ludności, opanowały Erewań i obszary przyległe. Wojska czerwonych znalazły się w okrążeniu, w bardzo trudnej sytuacji. Wówczas nadeszły posiłki z Rosji sowieckiej; całością akcji na miejscu kierował G.K. Ordżonikidze ${ }^{112}$. Padł Erewań; padły dalsze punkty oporu Ormian. Ostatni obrońcy wolności wycofali się w góry (tereny Zangezuru oraz częściowo Nachiczewanu i Karabachu), gdzie proklamowano Republikę Górskiej Armenii (premier i minister obrony narodowej - Garegin Nyżdeh ${ }^{113}$ ), która wkrótce zmieniła nazwę na Republika Armenii. W lipcu 1921 r. padła ostatnia reduta Ormian. Nie ustał jednak ich opór.

\section{OSTATNI ROZBIÓR ARMENII. SOWIECKA KONSTYTUCJA}

Komitet Wojskowo-Rewolucyjny unieważnił traktat aleksandropolski Armenii z Turcją. 16 marca 1921 r. na mocy moskiewskiego traktatu między Turcją a RSFRR ${ }^{114}$ ustalona została granica rosyjsko-turecka; m.in. w zamian za Kars

111 M. Zakrzewska-Dubasowa, op.cit., s. 239-240.

112 Ordżonikidze Sergo (właśc. Grigorij Konstantinowicz Ordżonikidze), 1886-1937, Gruzin, od 1903 r. aktywny w ruchu rewolucyjnym Zakaukazia, uczestnik październikowego zamachu stanu bolszewików w Piotrogrodzie, aktywny działacz zwłaszcza jako komisarz Armii Czerwonej na Ukrainie i na Kaukazie; brutalnie przeprowadzał akcje likwidujące fizycznie przeciwników politycznych na Zakaukaziu, wierny przyjaciel i sojusznik Stalina w rozgrywkach frakcyjnych, od 1927 r. na najwyższych stanowiskach partyjnych i państwowych; popełnił samobójstwo po starciu ze Stalinem, ale nie wyklucza się zabójstwa. Leksykon historii świata: Rosja, op.cit., s. 191; G. Przebinda, J. Smaga, op.cit., s. 211.

113 Garegin Nyżdeh (właśc. Garegin Ter-Harutiunian), ur. 1886 w Nachiczewanie, zm. w 1955 na Syberii lub w więzieniu we Włodzimierzu, ormiański polityk i generał, po ogłoszeniu niepodległości przez Demokratyczną Republikę Armenii współorganizował armeńską armię; walczył z Turcją; premier i minister obrony w rządzie efemerycznej Republiki Górskiej Armenii, do lipca 1921 r. prowadził z bolszewikami walkę partyzancką; podczas II wojny światowej próbował współpracować z Niemcami; w 1944 r. aresztowany przez sowietów w Sofii, skazany na 25 lat pozbawienia wolności.

114 16.03.1921 r. został w Moskwie podpisany układ o przyjaźni i braterstwie między RSFRR a Turcją. Rząd Kemala otrzymał od bolszewików znaczne sumy pieniężne oraz dużą pomoc w dostawach uzbrojenia dla armii. Dzięki temu Turcji udało się zwyciężyć w wojnie z Grecją. 
Rosja otrzymała Batumi. Formalnie tylko pośrednicząca RSFRR przeprowadziła zawarcie nowego traktatu między republikami zakaukaskimi a Turcją w Karsie (13.10.1921 r.), na mocy którego Kars, Ardahan i inne miasta i rejony otrzymała Turcja, natomiast Aleksandropol pozostawał przy Armenii, zaś Nachiczewań jako jednostka autonomiczna stał się częścią Azerbejdżanu. Tak dokonał się ostatni rozbiór Armenii. M. Zakrzewska-Dubasowa jeszcze w czasach komunistycznych pisała: „granica z Turcją była jedyną państwową granicą Rosji Radzieckiej, gdzie poczyniono znaczne ustępstwa kosztem Armenii. W rezultacie obszar republiki armeńskiej wynosi $29800 \mathrm{~km}^{2}$, podczas gdy Gruzja ma $69700 \mathrm{~km}^{2}$, natomiast Azerbejdżan $86600 \mathrm{~km}^{2}$. Ponadto oderwano od Armenii jej prastare prowincje, tworząc w ramach azerbejdżańskiej republiki autonomiczną republikę Nachiczewanu oraz w r. 1923 autonomiczny obwód Nagorno-Karabachski. Takie ustalenie granic jest nieustającym źródłem konfliktów wyznaniowych i narodowościowych i utrwala wśród Ormian uzasadnione poczucie krzywdy historycznej." 115

Na zjeździe delegatów robotniczych, chłopskich i żołnierskich w Erewaniu (30.01.-04.02.1922 r.) przyjęta została 2 lutego 1922 r. konstytucja ${ }^{116}$. Porządek obrad zjazdu przewidywał dziewięć spraw dużej - wydaje się - wagi; konstytucja znalazła się w punkcie drugim, po sprawozdaniu armeńskiej Rady Komisarzy Ludowych. Interesujące, że w następnym po konstytucji punkcie obrad przewidziano sprawę federacji republik zakaukaskich; nic nam nie wiadomo, co w tej ostatniej materii mówiono i czy zapadły jakieś uchwały. Ciekawe też, że punkt czwarty porządku obrad był poświęcony nowej polityce ekonomicznej; nie wiemy czy miało to być tylko wysłuchanie informacji, czy dyskusja.

Konstytucja składała się z 89 artykułów podzielonych na 5 rozdziałów. Rozdział pierwszy stanowił coś w rodzaju zasad ogólnych i nawet nazwą nawiązywał do konstytucji rosyjskiej z 1918 r.: „Główne zasady władzy eksploatowanego i pracującego ludu".

Na wstępie znalazła się deklaracja, że cała władza - tak centralna, jak i lokalna - w Armeńskiej Socjalistycznej Republice należy do rad robotniczych, chłopskich i żołnierskich. Do najwyższej rangi wyniesiono pracę i wprowadzono jej powszechny obowiązek wraz z zasadą, że „niepracujący - nie je”. Następnie, już w art. 4 tekstu konstytucji, ogłoszono nacjonalizację całej ziemi, lasów i wód, kolei, banków i wszystkich „dużych” (крупных) zakładów produkcyjnych. Jednocześnie konstytucja stanowiła o dopuszczeniu $w$ ramach prawa inicjatywy prywatnej (частная инициатива). To zupełna nowość w porównaniu z pierwszą konstytucją rosyjską z 1918 r., wówczas przecież obowiązującą. Należy jednak

115 M. Zakrzewska-Dubasowa, op.cit., s. 239.

116 История советской конституции. Сборник документов. 1917-1957..., s. 163-172; История советской конституции (в документах) 1917-1956..., s. 321-333. 
pamiętać, że od decyzji w sprawie NEP-u minęło już dziewięć miesięcy. Jeszcze w kwietniu 1921 r. Lenin „pozdrawiając gorąco Radzieckie Republiki Kaukazu” wskazywał, że w porównaniu do rozwiązań w Rosji należy zachować „więcej oględności, ostrożności, ustępliwości wobec drobnej burżuazji, inteligencji, a zwłaszcza chłopstwa" ${ }^{117}$.

Dopiero na dość odległym miejscu (art. 5), ledwie wzmiankowano o „rewolucyjnej dyktaturze robotników i pracujących chłopów", a i to jedynie w tym celu, by uzasadnić pozbawienie praw ludzi klasy eksploatatorskiej. Natomiast wcześniej (art. 2) ogłoszono równość wszystkich pracujących, bez względu na narodowość; nie wyrażono expressis verbis równości płci. Cerkiew oddzielono od państwa, a szkołę od cerkwi.

Jak wiele aktów radzieckiej władzy, konstytucja na papierze deklarowała takie wolności, jak wolność wyznania, słowa, niezawisłość druku, zgromadzeń, mityngów, demonstracji, ogłaszała powszechne bezpłatne nauczanie; wszyscy mieszkańcy Armenii mieli prawo do obywatelstwa. Natomiast zakazywała konstytucja nacjonalno-agresywnej polityki wobec sąsiednich państw i narodów; ogłaszała likwidację tajnej dyplomacji, deklarowała umocnienie dobrosąsiedzkich stosunków. Wprowadzała (art. 9) powszechną obowiązkową służbę wojskową w Armii Czerwonej Radzieckiej Socjalistycznej Republiki Armenii, ale nie dla wszystkich, tylko dla pracujących, zaś na inne osoby zapowiadała nałożenie innych obowiązków wojskowych.

Konstytucja ogłaszała (scil.: niezwłoczne) zlikwidowanie całego dotychczasowego prawa i wszystkich sądów (art. 10 pkt a) wszystkich byłych „kontrrewolucyjnych" rządów, a w to miejsce źródłem robotniczo-chłopskiego prawa staje się ustawodawstwo radzieckie, socjalistyczne przekonania i rewolucyjna świadomość. Podstawowymi sądami ustanowiono sądy ludowe, a także bliżej niesprecyzowane nadzwyczajne sądy w interesie robotniczo-chłopskiej rewolucji.

Część pierwsza kończyła się tekstem (art. 11) mającym charakter nie przepisu prawa, lecz manifestu ideologicznego o celach dyktatury proletariatu, a określono, że jest nim zlikwidowanie ustroju kapitalistycznego, wszelkiego rodzaju dyktatury, ułatwienie rewolucyjnego przewrotu i budowa socjalizmu. Ton tej wypowiedzi jest podobny, ale znacznie mniej agresywny niż część pierwsza (stanowiąca powtórzenie Deklaracji praw ludu pracującego i wyzyskiwanego) konstytucji rosyjskiej z $1918 \mathrm{r}$. Pewne podobieństwa to głownie powszechna nacjonalizacja, natomiast pozytywnie zanotować trzeba deklarację (chociaż papierową) o prawach i wolnościach obywateli, o prawie inicjatywy gospodarczej; w tej ostatniej spra-

117 Zob. odezwę Lenina Do towarzyszy komunistów Azerbejdżanu, Gruzji, Armenii, Dagestanu, Republiki Górskiej, [w:] W. Lenin, Dzieła wybrane, [bez tłumacza], t. 4, Warszawa 1978, s. $388-390$. 
wie widać upływ czasu i wejście w okres NEP-u. Konstrukcja całej konstytucji analogiczna, ale w treści ,podstawowych zasad” więcej różnic niż podobieństw z konstytucją rosyjską z $1918 \mathrm{r}$.

Rozdział drugi zatytułowany ,władza centralna” liczył 13 artykułów i podzielony był na dwie części; jedna poświęcona zjazdowi delegatów, zaś druga centralnemu komitetowi wykonawczemu. Zjazd określony został jako władza najwyższa. Składał się z delegatów wybieranych na zjazdach powiatowych w proporcji 1 delegat na 5 tysięcy osób, ale łącznie zjazd nie mógł liczyć więcej niż 300 delegatów. Szczegółowe przepisy w tej materii znalazły się w dalszej części konstytucji, przy regulacjach odnoszących się do rad lokalnych. Prawo wyborcze również znalazło się w dalszej części konstytucji. Przyznano je (scil.: bierne i czynne) wszystkim, którzy mieli ukończone lat 18, obojga płci, niezależnie od narodowości, wyznania, osiadłości, jak też żołnierzom krasnoarmiejcom; konstytucja enumeratywnie wymieniała osoby pozbawione praw wyborczych - „liszeńców”. $\mathrm{W}$ tej materii konstytucja Armenii nie pozostawała w tyle za rosyjską konstytucją z $1918 \mathrm{r}$.

Kompetencje Zjazdu zostały określone dopiero w dalszej części dokumentu (art. 37-38): do wyłącznej kompetencji Zjazdu należeć miała zmiana konstytucji, a nadto w sposób w istocie nieograniczony zakreślono kompetencje tego organu, tak w zakresie ustawodawczym, jak i wykonawczym, a były to m.in. zmiana granic Republiki, kontakty międzynarodowe, sprawy wojskowości, sprawy wojny i pokoju, powoływanie RKL, ustawodawstwo ustrojowe, dotyczące ustroju sądów, prawa cywilnego i karnego, amnestia, podział administracyjny kraju, sprawy finansów, pieniędzy, miar, wag.

Zjazd wybierał Centralny Komitet Wykonawczy (CKW) w liczbie nie mniejszej niż 75 osób. CKW był odpowiedzialny i podlegał kontroli Zjazdu, ale podobnie jak w konstytucji rosyjskiej - nie było żadnego uszczegółowienia co do rodzaju odpowiedzialności, jej form, procedury. CKW był między zjazdami najwyższym organem ustawodawczym, zarządzającym i kontrolującym. CKW wybierał swoje prezydium; zwoływał Zjazd; jako kompetencje CKW wskazano przygotowywanie projektów dekretów. Członkowie CKW mieli immunitet, który mogło uchylić prezydium (art. 23).

CKW powoływał Radę Komisarzy Ludowych [RKL] Socjalistycznej Republiki Armenii (art. 24). Kompetencje RKL, prawniczo niesprecyzowane i nieco chaotycznie wskazane, były (przynajmniej w bieżących sprawach) nieograniczone: ustawodawcze, wykonawcze, kontrolne. Dekrety i uchwały (постановления) RKL mogły być zmieniane przez CKW. Komisariatów i komisarzy ludowych było siedemnaście: spraw zagranicznych, spraw wewnętrznych, sprawiedliwości, oświaty, wojskowy, Najwyższa Rada Gospodarki, ziemski, finansów, aprowizacji, handlu wewnętrznego, pracy, ubezpieczenia społecznego, zdrowia, poczt i tele- 
grafów, Inspekcji Robotniczo-Chłopskiej, komunikacji. Zwraca uwagę istnienie resortu spraw zagranicznych, a brak resortu rolnictwa, chyba że rolę tę miał pełnić komisariat ziemski. W każdym resorcie powoływane być miały kolegia dla podejmowania decyzji, ale komisarz wyposażony został w prawo jednoosobowego podejmowania decyzji; $w$ przypadkach niezgodności z kolegium sprawę należało przedłożyć RKL (art. 33). Kolegia miały więc ograniczone uprawnienia, hamujące względem jednoosobowych decyzji komisarzy. To rozwiązanie analogiczne z konstytucją rosyjską. Szerokie też były kompetencje prezydium CKW (art. 3941), których nie ma potrzeby tu omawiać. Zjazd Rad, WCKW oraz RKL - wszystkie wyposażone były w kompetencje zarówno ustawodawcze, jak i wykonawcze oraz kontrolne, co stanowiło programowe przeciwstawienie się regule podziału władz; programowo odrzucono nawet zasadę ścisłego podziału kompetencji. Taka była też praktyka; panował pełny chaos ustawodawczy.

W konstytucji armeńskiej, analogicznie jak w rosyjskiej ustawie zasadniczej z 1918 r., klasy pracujące ukonstytuowane zostały jako klasy panujące, ale nie wolno zapominać, że tak było tylko w teorii, zaś faktycznie panowanie należało do partii komunistycznej, a nawet jeszcze węziej: do scentralizowanego aparatu partyjnego, o którym w Konstytucji nie było nawet wzmianki. Kamuflażem w systemie polityczno-prawnym było całkowite milczenie co do roli partii bolszewickiej. Tym samym partia pozostawała formalnie poza systemem konstytucyjnym, oficjalnie niemającym wpływu na życie publiczne. Rzeczywistość zaś w systemie totalitarnym, a szczególnie komunistycznym, we wszystkich krajach komunistycznych aż do końca istnienia systemu, była dokładnie odwrotna. Wszystkie decyzje, na każdym szczeblu, od najwyższego do najniższego daleko od Moskwy, podejmowane były w centralnych bądź terenowych organach biurokratycznego aparatu partyjnego, scentralizowanego w ramach całego państwa. W ten sposób zamiast dyktatury proletariatu skonstruowano system dyktatury partii komunistycznej, ze szczególną rolą partyjnego aparatu biurokratycznego.

Lokalnymi „najwyższymi” organami władzy ustanowione zostały rady delegatów, z ich organami zarządzającymi - komitetami wykonawczymi. Tworzone być miały na szczeblu najniższym we wsiach i miastach, na szczeblu wyższym w gminach (wołost), na szczeblu trzecim w powiatach (уезд). Wybory delegatów do Zjazdu Delegatów Robotniczych, Chłopskich i Żołnierskich były pośrednie: niższe szczeble wybierały delegatów na zjazd szczebla wyższego, aż w końcu zjazdy powiatowe wybierały zjazd republikański. W tym przedmiocie przepisy były drobiazgowe. System rad był ściśle hierarchiczny. Zasada bezpośredniości wyborów dotyczyła tylko organów najniższego szczebla. System zakładał rezygnację z zasady równości prawa wyborczego - radni ze wsi reprezentowali mniejsze grupy wyborców aniżeli radni z miast; w tej kwestii było dokładnie odwrotnie niż w konstytucji rosyjskiej, co pewnie wynikało ze specyfiki wiejskiego charakteru republiki. 
Kompetencje, a właściwie zadania rad lokalnych były określone ogólnikowo jako sprawy związane $\mathrm{z}$ danym terytorium, przy czym wyraźnie nacisk położono na wcielanie w życie wszystkich uchwał odpowiednich nadrzędnych organów władzy radzieckiej; w całości powtórzone zostały postanowienia konstytucji rosyjskiej. Centralizm demokratyczny był nieodłączną cechą ustawodawstwa sowieckiego.

Ostatni rozdział konstytucji ustanawiał herb i flagę Armeńskiej SRR.

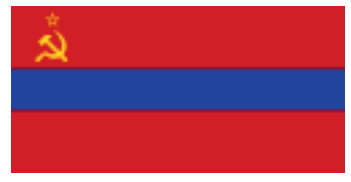

Flaga Armeńskiej SRR

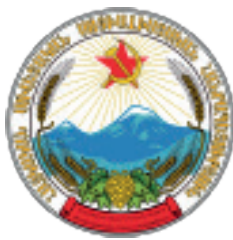

Godło Armeńskiej SRR

Konkluzja jest jedna: wzorzec konstytucji rosyjskiej z 1918 r. jest oczywisty, ale zauważalne jest wejście w inny okres historyczny, a mianowicie w NEP.

Sowiecka konstytucja Armenii z 1922 r. to signum utraty na lat siedemdziesiąt przez Armenię krótkiej niepodległości.

\section{ARMENIA'S JOURNEY TOWARDS PARTITION BY LENIN AND MUSTAFA \\ KEMAL (1917-1921)}

Abstract

After the February Revolution of 1917 in Russia, the former nations of the Russian Empire searched for the possibility of forming their own independent countries. The situation was the same with three nations of Transcaucasia, namely Armenia, Azerbaijan and Georgia. After the separatist Treaty of Brest-Litovsk (signed on the 3rd of March 1918), Bolshevik Russia in practice gave away the Transcaucasia region to Germany and Turkey. Especially Turkey assumed an aggressive and annexationist stance at the time. And it was the Armenians who mainly put up the resistance. Armenia, together with Azerbaijan and Georgia, first created the Transcaucasian Democratic Federative Republic. However, the state was short-lived and it soon collapsed due to different approaches to preserving independence by the three countries. Azerbaijan tried to unite with Turkey, Georgia with Germany, while Armenia counted on the White movement Russians (led by General Denikin). Each of the three countries formed separate independent republics and one of them was the First Republic of Armenia. Germany and Turkey lost the First World War soon after but Caucasia was first attacked from the north by the White General Anton Denikin, who was supported by England and France. And later (in 1920) the country was invaded by the Bolsheviks. The Bolsheviks, thanks to the military might of the Red Army, overthrew the 
independent governments of those republics one by one. Subsequently, they introduced their own governments and annexed the countries into the Russian Soviet Federative Socialist Republic (RSFSR). The RSFSR signed the Treaty of Brotherhood with Turkey on the 16th of March 1921, which was mainly directed against Great Britain and France. In order to realize this alliance, Russia and Turkey divided between themselves the Armenian lands.

\section{LE CHEMIN DE L’ARMÉNIE VERS LE PARTAGE LÉNINISTE-KÉMALISTE}

(1917-1921)

\section{Résumé}

Après la révolution de février 1917 en Russie, les nations de l'ancien Empire russe cherchaient les possibilités de créer leurs États indépendants. C'était également le cas des trois nations de la Transcaucasie: l'Arménie, l'Azerbaïdjan et la Géorgie. Après le traité séparatiste de Brześć (le 3 mars 1918), la Russie bolchevique a pratiquement cédé le territoire de la Transcaucasie à l'Allemagne et à la Turquie. La Turquie, en particulier, présentait une attitude agressive et annexionniste. C'étaient avant tout les Arméniens qui résistaient. L'Arménie, avec l'Azerbaïdjan et la Géorgie, a d'abord créé la République Fédérale Démocratique de Transcaucasie, mais elle s'est rapidement effondrée, car les trois pays préféraient emprunter des voies différentes pour sauver leur indépendance. L'Azerbaïdjan voulait se rapprocher de la Turquie, la Géorgie de l'Allemagne, et l'Arménie comptait sur les Russes «blancs» (le général Denikin). Chacun des trois pays a créé des républiques indépendantes distinctes: la République démocratique d'Arménie a été fondée. L'Allemagne et la Turquie ont bientôt perdu la guerre mondiale, mais le Caucase a été attaqué par le général «blanc» Anton Denikin, arrivant du nord et soutenu par l'Angleterre et la France.

Puis (en 1920), les bolcheviks sont entrés sur ces territoires. Avec les forces armées de l'Armée rouge russe, les bolcheviks ont renversé tour à tour les gouvernements indépendants de ces républiques, ils ont établi leurs propres gouvernements et incorporé ces pays dans la République socialiste fédérative soviétique de Russie (RSFSR). Le 16 mars 1921, la RSFSR a conclu un traité de fraternité avec la Turquie, visant à agir contre la GrandeBretagne et la France. Pour réaliser cette alliance, la Russie et la Turquie ont partagé les terres arméniennes. 